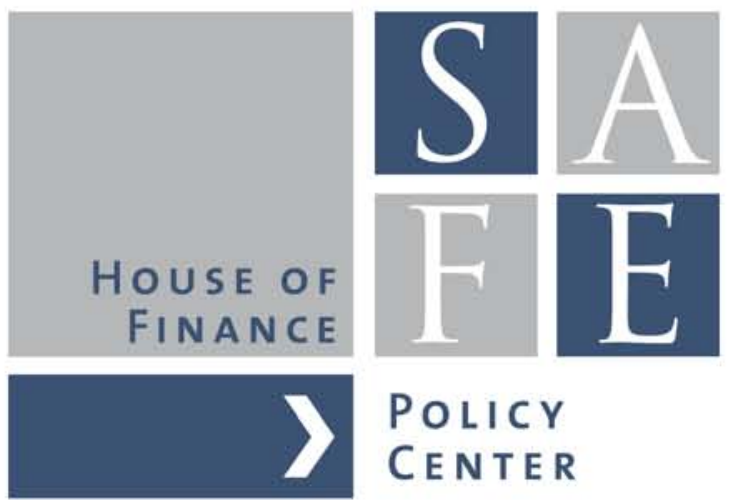

Sascha Steffen

\title{
Robustness, Validity, and Significance of the ECB's Asset Quality Review and Stress Test Exercise
}

White Paper No. 23

SAFE I Sustainable Architecture for Finance in Europe

A cooperation of the Center for Financial Studies and Goethe University Frankfurt 
This report was first published at the request of the Economic and Monetary Affairs Committee of the European Parliament, under the same title, on October 15, 2014.

SAFE Policy papers represent the authors' personal opinions and do not necessarily reflect the views of the Center of Excellence SAFE or its staff. 


\title{
Robustness, Validity, and Significance of the ECB's Asset Quality Review and Stress Test Exercise
}

\author{
2 November 2014 \\ Sascha Steffen ${ }^{1}$ \\ ESMT European School of Management and Technology
}

\begin{abstract}
As we are moving toward a eurozone banking union, the European Central Bank (ECB) is going to take over the regulatory oversight of 128 banks in November 2014. To that end, the ECB conducted a comprehensive assessment of these banks, which included an asset quality review (AQR) and a stress test. The fundamental question is how accurately will the financial condition of these banks have been assessed by the ECB when it commences its regulatory oversight? And, can the comprehensive assessment lead to a full repair of banks' balance sheets so that the ECB takes over financially sound banks and is the necessary regulation in place to facilitate this? Overall, the evidence presented in this paper based on the design of the comprehensive assessment as well as own stress test exercises suggest that the ECB's assessment might not comprehensively deal with the problems in the financial sector and risks may remain that will pose substantial threats to financial stability in the eurozone.
\end{abstract}

\footnotetext{
${ }^{1}$ ESMT European School of Management and Technology, Schlossplatz 1, 10178 Berlin (Germany), email: steffen@esmt.org, phone +49 (30) 21231 - 1544, fax: +49 (30) $21231-1281$.

I thank Viral Acharya, Claudia Buch, Martin Hellwig, Jan Krahnen, Marco Pagano, and Dirk Schoenmaker for valuable comments and suggestions. This paper is based on an earlier version the paper "Robustness, Validity, and Significance of the ECB's Asset Quality Review and Stress Test Exercise" for the EU Parlimanet that is available here: http://www .europarl.europa.eu/document/activities/cont/201410/20141024ATT91766/20141024ATT91766EN.pdf (ISIN 97892-823-6063-7).
} 


\section{TABLE OF CONTENTS}

$\begin{array}{ll}\text { LIST OF ABBREVIATIONS } & 5\end{array}$

LIST OF FIGURES

LIST OF TABLES

LIST OF KEY FINDINGS

$\begin{array}{ll}\text { EXECUTIVE SUMMARY } & 7\end{array}$

$\begin{array}{lc}\text { 1. INTRODUCTION } & 8\end{array}$

2. STRESS TESTS AFTER THE 2007-2009 FINANCIAL CRISIS 10

3. ECB'S 2014 COMPREHENSIVE ASSESSMENT 11

3.1. Objective and Scope of the Comprehensive Assessment 12

3.2. Asset Quality Review

3.3. Design and Execution of EBA 2014 Stress Tests 13

3.3.1. Stress test scenarios and modeling approach $\quad 14$

3.3.2. Stress test outcome $\quad 15$

4. SYSTEMIC RISK AND IMPLICATIONS FOR STRESS TESTING 17

$\begin{array}{lll}\text { 4.1. } & \text { Systemic Risk and Contagion } & 18\end{array}$

4.1.1. Contractual contagion or domino effects 18

$\begin{array}{lr}\text { 4.1.2. Information contagion } & 18\end{array}$

4.1.3. Fire sale contagion $r$

4.1.4. Price complexity externalities $r$

4.2. Common Exposures $\quad 19$

4.3. Implications for stress testing $\quad 20$

5. ALTERNATIVE STRESS TESTING MODELS USING PUBLIC DATA 21

5.1. Alternative Macroprudential Stress Test Models $\quad 22$

5.2. Alternatives to the EBA 2011 Stress Test 22

5.2.1. Steffen (2011) and Acharya and Steffen (2013) 22

5.2.2. Acharya et al. (2014) 23

5.3. An Alternative to the EBA 2014 Stress Test 24

5.3.1. Cross-country capital shortfalls using book and market stressed capital ratios 26

5.3.2. Ranking banks with largest capital shortfalls using SRISK 27

5.3.3. Assessing Losses Based on Write Downs of Non-Performing Loans 27

5.3.4. Comparing shortfalls based on regulatory and book (or market) stressed capital ratios 28

6. CONCLUSION 2

REFERENCES

ANNEXES
34 


\section{LIST OF ABBREVIATIONS}

\begin{tabular}{|c|c|}
\hline AFS & Available for Sale \\
\hline AIG & American International Group, Inc. (U.S.-based insurance company) \\
\hline AQR & Asset Quality Review \\
\hline $\mathrm{BHC}$ & Bank Holding Company \\
\hline BRRD & Bank Recovery and Resolution Directive \\
\hline $\mathrm{C}$ Tier 1 ratio & Common Equity Tier 1 ratio (CRD III/Basel 2.5) \\
\hline CCAR & Comprehensive Capital Analysis and Review \\
\hline CDS & Credit Default Swap \\
\hline CEBS & Committee of European Banking Supervisors \\
\hline CET1 & Core Equity Tier 1 capital (CRR/CRD IV; Basel 3) \\
\hline CoVaR & Co-movement Value-at-Risk \\
\hline CRD III & Directive 2010/76/EU \\
\hline CRR/CRD IV & Regulation (EU) No 575/2013 and Directive 2013/36/EU \\
\hline DFA & Dodd-Frank Act \\
\hline DIP & Distressed Insurance Premium \\
\hline EBA & European Banking Authority \\
\hline EC & European Commission \\
\hline $\mathrm{ECB}$ & European Central Bank \\
\hline ECOFIN & Economic and Financial Affairs Council \\
\hline ESM & European Stability Mechanism \\
\hline ESRB & European Systemic Risk Board \\
\hline EU & European Union \\
\hline Fed & Federal Reserve Bank \\
\hline GDP & Gross Domestic Product \\
\hline GIIPS & Greece, Ireland, Italy, Portugal, Spain \\
\hline HFT & Held For Trading \\
\hline HTM & Held to Maturity \\
\hline IFRS & International Financial Reporting Standards \\
\hline IMF & International Monetary Fund \\
\hline IRB & Internal Ratings-Based Approach \\
\hline LRMES & Long-run Marginal Expected Shortfall \\
\hline LTRO & Long-Term Refinancing Operation \\
\hline LVG & Leverage \\
\hline MES & Marginal Expected Shortfall \\
\hline NCA & National Competent Authority \\
\hline NPL & Non-performing Loans \\
\hline NSA & National Supervisory Authority \\
\hline OMT & Outright Monetary Transaction \\
\hline $\mathrm{P} \& \mathrm{~L}$ & Profit and Loss \\
\hline QA & Quality Assurance \\
\hline RWA & Risk-Weighted Assets \\
\hline SCAP & Supervisory Capital Assessment Program \\
\hline SES & Systemic Expected Shortfall \\
\hline SME & Small- and Medium-size Enterprise \\
\hline SMP & Securities Markets Program \\
\hline SRISK & Systemic Risk Measure \\
\hline SSM & Single Supervisory Mechanism \\
\hline USD & U.S. Dollar \\
\hline
\end{tabular}




\section{LIST OF FIGURES}

FIGURE 1. Crowding-out of Lending in Italy and Spain 9

FIGURE 2. Correlation of Capital Shortfalls 29

\section{LIST OF TABLES}

TABLE 1. Top 10 banks with largest (percentage) capital shortfalls: July 2010 vs. July 201123

TABLE 2. Sample of ECB Stress Test Banks: Descriptive Statistics 26

TABLE 3. Capital Shortfalls Using Book Capital Measures $\quad 27$

TABLE 4. Capital Shortfalls Using Book and Market Capital Shortfalls 27

TABLE 5. Write Down of NPL Portfolio 28

\section{LIST OF KEY FINDINGS}

BOX 1. Key Findings: - Stress Test Review 10

BOX 2. Key Findings: EBA 2014 Stress Test Exercise 11

BOX 3. Key Findings: Systemic Risk and Implications for Stress Testing 17

BOX 4. Key Findings: Alternative Stress Test Models 22 


\section{EXECUTIVE SUMMARY}

The European Central Bank (ECB) will take over the regulatory oversight of 128 banks in the eurozone in November 2014. The ECB will effectively assume roles as both central bank and regulator in charge of the Single Supervisory Mechanism (SSM). In preparation, the ECB conducted a comprehensive assessment of these banks, which included an asset quality review (AQR) and a stress test. The credibility of the ECB might be severely damaged if these banks fail because of legacy assets soon after it takes over regulatory oversight. The comprehensive assessment was thus necessary to clean up banks' balance sheets before the takeover.

The banking system in the eurozone is still vulnerable. During the credit boom of 2004-2006, banks invested too much and accrued too much leverage. Importantly, they did not internalize how their behavior affects the entire financial system. This became obvious during the 2007-2009 global financial crisis, as well as during the recent sovereign debt crisis when banks incurred massive losses and needed substantial government support. European stress tests were implemented in 2010 and 2011 as part of macroprudential oversight; however, they were ineffective. Substantial solvency concerns with respect to some institutions remained and caused a disruption in short-term funding markets in the fall of 2011. The ECB thus implemented a tailor-made monetary policy to support these institutions, further reducing incentives of banks and national regulators to act.

The ECB faces a trade-off: On the one hand, it wants to maintain its reputation as a central bank and build its reputation as a regulator from the start by comprehensively identifying and valuing the problem assets of the 128 banks. On the other hand, there is the potential for capital shortfalls but no clearly defined backstops should any of the banks falter. Worse, national regulators may have incentives that induced them to not fully disclose problem assets, yet the ECB depended on information from the national regulators when conducting the comprehensive assessment. The trade-off may have weakened the significance of both the AQR and the stress test exercise.

Stress tests are supposed to be part of the macroprudential regulation of banks. However, regulators still have to incorporate the interconnectedness of the financial system in the way they regulate banks. Banks are increasingly interconnected through contractual relationships, as well as exposures to similar assets and similar comparable macroeconomic shocks. Because banks do not internalize the risks their behavior creates for the system, they invest too much and accrue too much leverage. The ECB's comprehensive assessment does not account for this "systemic risk."

Taken together, the trade-off faced by the ECB, as well as the omission of systemic risk in the assessment, strongly suggest that the ECB may not be able to reach its objective to identify the problem assets and cleanup the balance sheets of European banks, putting its reputation in danger and leaving the financial system vulnerable. The ECB may thus have to continue providing assistance to banks about whose solvency one can have serious doubts. Importantly, a sustainable growth path still eludes the eurozone countries and the results in this report further increase doubts that Europe can escape this low-growth environment in the near future.

In this report, I describe alternative stress test models that rely on public data. These models account for, among other items, systemic risk. They have produced results consistent with economic developments in 2010 and 2011 and provide interesting findings using the banks included in the comprehensive assessment. These models can serve as credible benchmarks for the comprehensive assessment, as well as future stress tests. 


\section{INTRODUCTION}

In November 2014, the European Central Bank (ECB) is going to take over the regulatory oversight of 128 banks in the eurozone. To facilitate this step toward a banking union, the ECB has conducted a comprehensive assessment of these banks, which has included an asset quality review (AQR) and a stress test.

While European banks did undergo stress tests in 2010 and 2011, the political stakes in the current one are much higher. The main objective in 2010 and 2011 was to assess the resilience of the banking system to different risk factors. These tests, however, which were designed by the European Banking Authority (EBA), have widely been criticized. Beginning in November 2014, the ECB will effectively assume roles both as central bank and regulator in charge of the Single Supervisory Mechanism (SSM). ${ }^{2}$ The credibility of the ECB might be severely damaged if banks fail due to legacy assets soon after the ECB commences regulatory oversight. A comprehensive assessment was thus necessary to evaluate the financial soundness of these banks and clean up their balance sheets before ECB oversight begins.

The shortcomings of the 2010 and 2011 stress tests to some extent due to the incentives and to the constraints of the national supervisors in dealing with eurozone banks. First, they had not been successful in preventing an excessive build-up of risk in the financial system before the recent financial crisis. ${ }^{3}$ More importantly, in some cases they have been slow in dealing with the writedown needs of banks, ignoring the risks and deferring problems to the future. Secondly, some problem banks may simply have been too large and resolution too costly and regulators may have tried to avoid a public outcry over bank failures and costs to taxpayers; or the countries may not have had the fiscal capacity to effectively resolve the problems. Finally, regulatory forbearance might have been politically motivated due to strong ties between banks and politicians. ${ }^{4}$

Moreover, the actions of the ECB to support the eurozone economy through the Securities Markets Programme in 2010 and 2011, Long-Term Refinancing Operations (LTRO) in 2011 and 2012, and the announcement of the Outright Monetary Transactions (OMT) program in 2012 provided support to a troubled financial system, thereby making it possible to delay dealing with troubled banks. Repeatedly lowering its collateral standard, the ECB was effectively providing assistance to banks that likely had solvency issues. ${ }^{5}$ Thus, national regulators may have had even more incentives to defer actions as the problem was partly addressed by the ECB. The ECB's comprehensive assessment should contribute to curtailing such forbearance by national regulators. Using a single framework for the identification and valuation of non-performing loans, for example, and relying on a common supervisory benchmark should help remove undue forbearance and clean up financial institutions.

The weak and uneven economic recovery in Europe supports this narrative. Europe, and the southern countries in particular, were mired in recession from early 2011 to 2013 and a sustainable growth path still eludes them. A big problem is the small scale of lending especially to small and medium enterprises (SME) in the eurozone. The scarcity of bank capital appears to have caused a

\footnotetext{
${ }^{2}$ The advantages and disadvantages of combining both roles are not discussed here. Goodhart (1988) and Hellwig (2014c) provide extensive discussions on the topic.

${ }^{3}$ While the counter-cyclical capital buffers that were introduced in Spain helped to smooth the effects at the beginning of the crisis, they eventually appeared to be too small.

${ }^{4}$ Hellwig (2014a and 2014b) provide an in-depth discussion of these issues.

${ }^{5}$ ECB support was most important for weakly capitalized banks (Acharya and Steffen, 2014b).
} 
misallocation of credit in the area, preventing a widespread economic recovery. Moreover, undercapitalized banks loaded up on risky sovereign bonds, which destabilized the banks even further, resulting in substantial liquidity, and solvency problems, and a crowding out of lending to nonfinancial firms (Acharya and Steffen, 2014). ${ }^{6}$ The crowding out effect is shown in Figure 1 using ECB data.
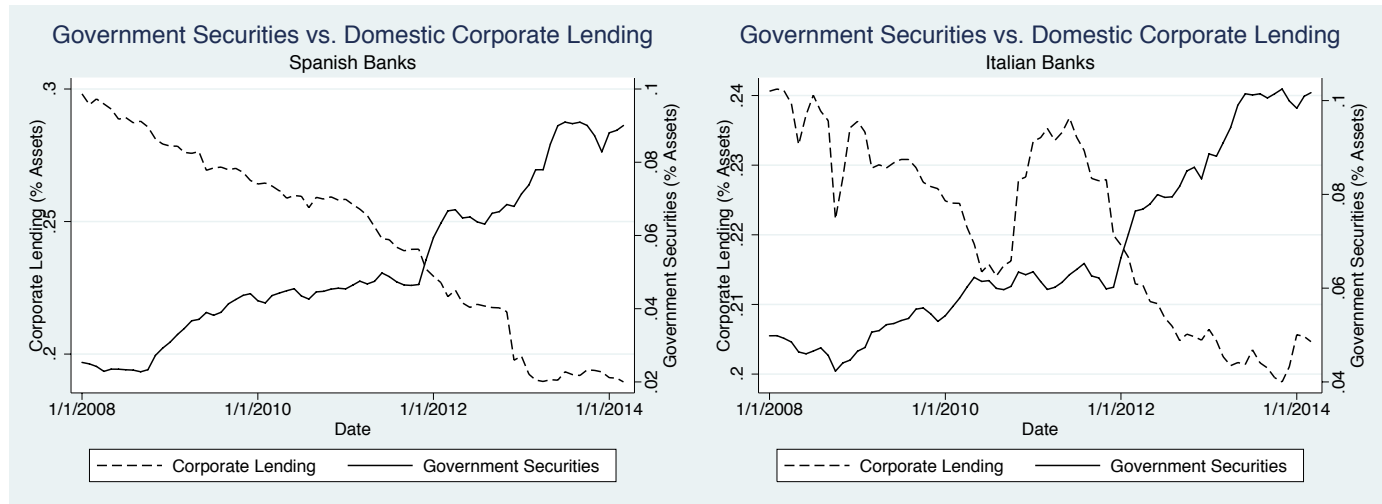

FIGURE 1. Crowding-out of Lending in Italy and Spain

This theme is reminiscent of the Japanese banking crisis of the 1990s (Peek and Rosengren, 2005; Caballero, Hoshi, and Kashyap, 2008; Hoshi and Kashyap, 2010). The lack of capital prevents a cleaning-up of European banks' balance sheets, which are still bloated from the 2004-2006 credit boom, and have not been properly addressed by national regulators. This in turn prevents an efficient allocation of credit throughout the economy.

The rationale for the comprehensive assessment is twofold: First, there is the political or institutional narrative that the ECB wants to preserve its credibility as a central bank and to establish its authority as a supervisor at the implementation of the SSM. Second, a serious comprehensive assessment is imperative to identify and repair existing capital shortfalls within the banking sector to facilitate efficient capital flow, restore credit, and reignite economic growth in the eurozone.

The fundamental question is: in what condition is the euroarea banking system as the ECB eventually assumes responsibility of the largest banks in the eurozone? And, can the comprehensive assessment lead to a complete repair of banks' balance sheets so that the ECB takes over the regulatory oversight of financially sound banks? The design of the assessment may not comprehensively deal with the problems in the banking sector and the risks remaining on the balance sheets may still pose substantial risks to financial stability in the region. ${ }^{8}$ The reasons for these observations are discussed in this report.

\footnotetext{
${ }^{6}$ In fact, if diversification does not reduce banks' capital requirements, loading up on one asset becomes a rational response (Acharya et al., 2014).

${ }^{7}$ Popov and van Horen (2013), for example, report that it has taken European banks much longer to recover in terms of their global syndicated lending than other banks, largely due to their GIIPS holdings. Schoenmaker (2013) also suggests that weak banks reduced corporate lending while increasing their holdings of risky peripheral sovereign debt.

${ }^{8}$ Moreover, as long as these risks are still a concern, differential access of banks to market funding will persist; the need for the ECB to provide liquidity to these institutions may persist as well.
} 
This paper is structured as follows. I start with a brief discussion of the criticism and shortcomings of the 2010 and 2011 European stress tests. To what extent have these shortcomings been addressed in the design of the new stress test? Moreover, how does the design of the ECB's 2014 stress test compare to those that have been performed in the United States since 2009? A central part of my analysis is devoted to systemic risk and its implications for stress testing. As national regulators have a microprudential perspective, important externalities might not have been adequately considered in the way banks are regulated. Thus, these externalities may pose substantial threats to the financial system. And can we use alternative stress test models based on market data as credible benchmarks for regulatory stress tests?

\section{STRESS TESTS AFTER THE 2007-2009 FINANCIAL CRISIS}

\section{KEY FindingS}

- The stress test that was conducted in the U.S. in 2009, the Supervisory Capital Assessment Program (SCAP), was successful because (1) the stress scenarios were severe, (2) public backstops were available from the U.S. Department of the Treasury, and (3) sufficient information was disclosed to mitigate solvency concerns.

- The 2010 and 2011 European stress test scenarios have been criticised as being too lenient. They also did not sufficiently address important risk factors, such as sovereign risk.

- Solvency concerns led to a disruption in short-term funding markets in the fall of 2011. As a result, the ECB implemented a tailor-made monetary policy to support weak financial institutions, further reducing incentives of banks and national regulators to act.

\section{BOX 1. Key Findings: Stress Test Review}

Since the 2007-09 financial crisis, stress tests have become an integral part of macroprudential regulation in the U.S. and Europe with the goal to strengthen the resilience of the financial system and ensure that financial institutions have sufficient capital. The experience in the U.S. and Europe, however, has been very different.

The U.S. started its first stress test in 2009, called the Supervisory Capital Assessment Program (SCAP), which was widely perceived as successful. The assessment included 19 banks (which accounted for two-thirds of total assets in the U.S.) and calculated a combined capital shortfall of $\$ 75$ billion, which was raised in private markets six months after the tests. The stress test was successful for three reasons: First, the scenario that was used to calculate losses was sufficiently severe. Second, if banks were not able to raise capital in private markets, the U.S. government's Capital Assistance Program (CAP) provided a credible backstop. Third, SCAP disclosed sufficient information to investors to increase transparency with respect to the solvency of the assessed banks. ${ }^{9}$

The European experience was different: stress tests in 2010 and 2011 have been widely criticized.

\footnotetext{
${ }^{9}$ I do not discuss the benefits or costs of disclosing stress test related information in this paper.
} 
The Committee of European Bank Supervisors (CEBS), the predecessor of the European Banking Authority (EBA), conducted the 2010 stress test using a sample of 91 banks. The total estimated shortfall amounted to $€ 3.5$ billion for all banks. The 2011 stress test performed by the EBA comprised 90 banks, and only eight banks were eventually required to raise a total of $€ 2.5$ billion in capital. These stress test scenarios have been criticised as being too lenient, as well as not giving sufficient importance to risk factors such as sovereign risk. ${ }^{10}$

Substantial solvency concerns with respect to some financial institutions remained after the European stress tests, causing a disruption in short-term funding markets in the fall of 2011. The ECB thus started a tailor-made monetary policy through the Securities Markets Program in 2010 and 2011, Long-Term Refinancing Operations (LTRO) in 2011 and 2012, and the announcement of the Outright Monetary Transaction (OMT) program in 2012 to support these institutions, further reducing the incentives of banks and national regulators to act.

\section{ECB's 2014 COMPREHENSIVE ASSESSMENT}

\section{KEY FindingS}

- The ECB would like to clean up the balance sheets of Europe's largest banks to retain its integrity and reputation as a central bank and establish credibility as regulatory supervisor of these banks.

- The ECB to some extent depends on national regulators in carrying out the assessment of eurozone banks. Regulators (who are usually not independent from national governments) may be tempted to not disclose large shortfalls.

- The AQR is at the heart of the comprehensive assessment as it was supposed to identify the problem assets in the financial system. However, little information is available about the mechanics of the AQR. The key problems: Are all relevant asset classes identified? And, how should these assets be valued? Asset valuation entails a substantial amount of subjectivity and discretion.

- The design of the 2014 ECB stress test is a substantial improvement over the 2010 and 2011 European exercises including, for example, more banks, different macro-scenearios and more risk factors.

- Credible fiscal backstops are unclear. The lack of clarity regarding public backstops may have induced the ECB to water down the stress test scenarios.

- The use of risk-weighted assets as part of the regulatory capital ratio leaves banks with too much leverage if risk weights do not adequately reflect asset risk. The use of risk-weighted assets might also lead to an increase in the interconnectedness among institutions (e.g. when all banks increase their exposure to the same risky sovereign bonds), which exacerbates the risks to the financial system.

BOX 2. Key Findings: EBA 2014 Stress Test Exercise

\footnotetext{
${ }^{10}$ The EBA performed a capitalization exercise in September 2011. It required banks to hold an additional capital buffer to account for risks associated with sovereign debt. This indicates that the 2010 and 2011 stress tests were not sufficiently strict with respect to this risk factor.
} 


\subsection{Objective and Scope of the Comprehensive Assessment}

The ECB will take over the regulatory oversight of 130 large eurozone banks in November $2014 .^{11}$ To that end, it has conducted a comprehensive assessment of these banks, which included an AQR and a stress test.

As described above, the ECB would like to clean up the balance sheets of Europe's largest banks. However, there are at least two aspects that may affect its incentives. First, who is going to pay if shortfalls are identified? Will banks be able to raise funds in private markets? Or, are there national public backstops to cover the shortfalls that cannot be raised in private markets? Are there eurozone-wide public backstops if the sovereign does not have the capacity to provide the funds? I discuss the problem of recapitalizing the banks in subsection 3.3.2, as it deserves a separate discussion.

Second, are there diverging interests between the ECB and national regulators? National regulators (who are not usually independent from their national governments) may have incentives that induce them to not disclose the full extent of problem assets. This is an important concern. The ECB has a substantial informational disadvantage vis-à-vis national regulators. However, it relied to some extent on the information from national regulators to conduct the assessment. Of course, national regulators do have incentives to keep the capital shortfalls as small as possible, with the intention at some point to share the burden with other countries. These incentives are particularly strong for countries with weakly capitalized banks and limited fiscal capacity.

Both aspects have implications for the design of both the AQR and the stress test. The ECB might be induced to dilute the tests ex ante to avoid a major burden on the national sovereigns. ${ }^{12}$ This, however, conflicts with the primary objective of the ECB and puts its future reputation as a central bank and a regulatory overseer at risk. Moreover, it increases the likelihood that the ECB needs to continue with a monetary policy tailored to weak banks.

Additionally, a weak comprehensive assessment does a serious disservice to the transparency of the comprehensive assessment and of eurozone banks' balance sheets. In 2011, when the extent of the influence of sovereign bonds on banks' balance sheets became visible, short-term investors (such as U.S. money market funds) substantially reduced their funding to banks with large exposures to risky sovereign debt because they questioned the solvency of these institutions. A decisive comprehensive assessment is supposed to increase balance sheet transparency and reduce solvency concerns in order to open private funding markets to European banks; for many banks, these markets are still out of reach.

\footnotetext{
${ }^{11}$ Smaller banks will be directly supervised by national regulators and "indirectly" supervised by the ECB. National regulators are responsible for conducting AQRs as part of their regulatory assessment. Note that small banks are not less important in terms of their systemic importance as many failures by them can turn into a systemic crisis also on a European level. For example, Banco Espirito Santo, one of the 128 banks the ECB is supposed to take over and a relatively small bank with assets of about $€ 81$ billion, defaulted in July 2014, causing a global stock market decline. Raffeisenbank Schweiz Genossenschaft, a bank with assets of around $€ 28$ billion, has recently been declared a systemically important financial institution in Switzerland because its products cannot easily be replaced but are of great importance for the Swiss economy.

${ }^{12}$ The Treaty on Stability, Coordination and Governance (TSCG), also called the "fiscal compact," which entered into force on January 1, 2013, puts further pressure on the flexibility of sovereigns' budgets.
} 


\subsection{Asset Quality Review}

The Asset Quality Review (AQR) is the first part of the comprehensive assessment. The AQR is a point-in-time assessment of the eurozone banks' loan books with the goal of identifying problem assets. This part of the assessment is crucial given the objective described in the introduction. If the ECB wants to assume regulatory responsibility for a healthy financial system, it has to start by analyzing the balance sheets of banks in as much detail as possible, identifying which assets are problematic, and requesting remedial measures where appropriate (ECB, 2014b). There is not much information available as to how the $\mathrm{AQR}$ was actually performed; however, a few points are worth mentioning about the $\mathrm{AQR}$ process.

Identify problem assets: The AQR should have uncovered the non-performing assets that are still on the balance sheets of the 128 banks. Non-performing asset examples might be Irish or Spanish real estate loans or the shipping loans of German banks. The value of these loans needs to be adjusted to reflect the increase in credit risks that have been caused by the real estate and shipping crises. While credit risks are always hard to quantify, decreases in the market value of collateral provides some indication of write-down needs. And in some cases where market values of collateral are unavailable because the crisis led to a market freeze (to which the banks, fearing the consequences of market transparency, may have even contributed), the market freeze itself should be taken as a signal for write-down needs. Moreover, the AQR considers only a fraction of a bank's loan book that has been selected for this exercise. Thus, problem loans might still be hidden in banks' balance sheets, as they were not evaluated.

Valuation: How are assets valued? Loans do usually not have market prices. Should discounted cash flows be used instead? How are cash flows estimated? How are discount rates determined? Valuations of loans are thus very subjective. Should we trust market prices if they are available? Or are they depressed and deviating from fundamental value?

Combining the AQR and the stress test: How are the results from the AQR reflected in the stress test? Conceptually, the AQR should have preceded the stress test and the results from the AQR should fully enter the stress test exercise. The AQR and stress test, however, were conducted in parallel. The ECB has recently published the methodology on how the AQR and stress test have to be combined (ECB, 2014a). I still have some reservations regarding this process. While the results from the AQR are used in the stress test, the ECB could not fully disclose the results to the banks in order not to trigger mandatory disclosures by banks to investors. Instead, the ECB constructed adjustments that the banks are supposed to use ("join up"). These adjustments seem to exhibit a certain amount of discretion on the side of the ECB. They might be used to attenuate the requirements of the comprehensive assessment ex post, as described above.

\subsection{Design and Execution of EBA 2014 Stress Tests}

I investigate the stress test as the second part of the comprehensive assessment in the remainder of the paper and raise concerns as to the consistency of the approach with the main objective of this exercise. In this subsection I discuss the issues surrounding the (1) scenario of the tests, (2) the modeling approach, and (3) the evaluation of the results. I focus on key aspects to keep the discussion manageable and to avoid a subjective bias by being too detailed with respect to, for 
example, scenario realizations. I address the design of the EBA $2014^{13}$ scenarios (as well as model choice and outcome) in depth in the annexes.

1. Annex I provides an in-depth comparison of the EBA 2011 and EBA 2014 stress tests.

2. Annex II provides a detailed overview of (1) the adverse scenarios in 2014 versus the adverse scenario in 2011 and (2) versus the actual economic development 2011-2013 with respect to the following macroeconomic factors: GDP, unemployment, inflation, government bond yields, and house prices. I focus on the eurozone, Germany, and the GIIPS (Greece, Italy, Ireland, Portugal, and Spain) for comparison. The interested reader can easily compare these factors across the different countries.

3. Annex III provides a comparison between the stress tests that have been conducted in the US, the Comprehensive Capital Analysis and Review (CCAR) 2014 and EBA 2014.

\subsubsection{Stress test scenarios and modeling approach}

The design of the EBA 2014 stress test exercise is a substantial improvement over the previous exercises in 2010 and 2011 in various aspects. For example, a larger number of banks are included, the scope of macro shocks as well as country-specific shocks is substantially broader (also compared to the U.S.), ${ }^{14}$ a wider range of risks is considered (also counterparty risk when assessing market risk), and national authorities are encouraged to add other country-specific risks as well (even though these will not enter the overall assessment to ensure comparability). Several other issues are worth highlighting (also comparing the EBA 2014 and EBA 2011).

Severity of stress tests: A frequently discussed question is: Are the stress test scenarios severe enough? The adverse scenario is not based on a historical scenario but on a series of shocks, as described in Annex I, that have been constructed by the EBA/ESRB using historical data, along with their judgment. This makes it difficult to compare the stress test to other tests or time periods. Should the answer to that question be based on how many banks "fail" the stress test or whether or not a bank fails on the ECB's watch shortly after the tests, as happened in 2010 and 2011? A better question to ask may be: Are there reasons to assume that the stress tests might be deliberately weak in the first place? And the answer to that question would be yes. Conflicting incentives of the ECB and national authorities and missing public backstops make it more likely that the stress scenarios are too weak to avoid large capital shortfalls that cannot be financed with public funds.

Consistency of the stress test scenarios: Unfortunately, it is impossible to investigate the consistency of the adverse stress scenario using the information provided in the methodology note for at least two reasons. First, the time series data of many of the macro variables are not publicly available for several countries (not on Bloomberg, Datastream or other public sources), surprisingly even for standard information such as GDP. Second, based on the description of the modeling approach, a replication of the scenario is hardly feasible. Given the shocks that enter the model, it would have been interesting to see the responses of the various macro factors that eventually enter

\footnotetext{
${ }^{13}$ EBA 2014 is simply a notation for the EBA stress test in 2014; the stress tests in 2010 and 2011 are abbreviated with EBA 2010 and EBA 2011, respectively.

${ }^{14}$ Of course, a higher degree of complexity (e.g., through several macro variables and countries) increases the risk that the models are not correctly specified. I will return to this issue in the section 5 of this paper.
} 
the adverse scenario. ${ }^{15}$ As the ECB may have incentives to make the scenarios weaker (at least for some banks), a consistent modeling approach for the stress test would have been reassuring and helped to increase transparency.

Horizon and static balance sheet assumption: A striking difference compared to EBA 2011 is the choice of a three-year stress test horizon instead of two years. This can be interpreted as a higher risk aversion by the ECB, which supports their objective to accept responsibility of a financially sound group of banks. However, the rather long horizon is problematic because of the static balance sheet assumption. In other words, even though a bank is confronted with, for example, a three-year recession, it is assumed to not change its business model, sell assets or change its funding structure. ${ }^{16}$ This tends to ignore any behavioral and feedback effects, which eventually pose substantial risks to the financial system. I discuss these issues in detail in the next section.

Liquidity risk: Liquidity risk is still not explicitly modeled in EBA 2014 stress test. While it is indirectly accounted for through an increase in funding costs, different funding structures (i.e., the relative reliance on wholesale funding) are not modeled, nor are bank runs by short-term investors and, in particular, runs on the financial system as a whole.

Bottom-up approach: The ECB relies on the information provided by the banks (who conduct the stress test using internal models) and the national regulators who are in close contact with the national banks in order to assure the validity of the information. This process emphasizes the relevance of the incentive problems of the national regulators and government not to disclose the extent of the capital shortfalls of their banks.

\subsection{2. $\quad$ Stress test outcome}

The stress test outcome can be assessed based on how the stress test results are evaluated, as well as the consequences that follow.

Common Equity Tier 1 capital ratio and thresholds: The comprehensive assessment follows the capital definition of the CRR/CRD IV with transitional rules and the partial removal of the prudential filters. As in EBA 2011, the 2014 assessment uses a single capital ratio to assess the outcome of the AQR and stress test, the Common Equity Tier 1 capital ratio. ${ }^{17}$ The ECB gives national regulators the opportunity or encourages them to use different leverage ratios and stricter thresholds. The latter, however, may not have incentives to make the tests even stricter to contain possible shortfalls.

Risk-weighted assets: Similar to 2011, the 2014 stress test uses a regulatory capital ratio, whose denominator is risk-weighted assets. Acharya et al. (2014) show that the use of risk-weighted assets to some extent explains the outcome of the 2011 stress test. Using regulatory capital ratios rests on

\footnotetext{
${ }^{15}$ The Federal Reserve Bank provides the raw data on its website (http://www.federalreserve.gov/bankinforeg/stresstests/2014-appendix-a.htm).

${ }^{16}$ The effect of the static balance assumption on bank risk is ambiguous. Suppose that a bank changes its business model as to mitigate consequences of a shock, e.g. by raising equity, then this assumption tends to exaggerate the effect of the shock on bank risk. However, and I will describe this in detail in section 4, if the shock leads to contagion and fire-sales, the effect on bank risk will be underestated.

${ }^{17} \mathrm{I}$ discuss the use of multiple ratios in the final section.
} 
the crucial assumption that the risk weights correctly reflect the risks of the asset. Sovereign debt is a particular example that demonstrates that this is not the case. The sovereign debt crisis made clear that sovereign debt is risky; however, regulators have not yet made an attempt to increase risk weights, which are still zero in the standardized approach of Basel III. ${ }^{18}$ Underestimating the risk of sovereign debt leaves banks with too much leverage. Moreover, it increases the interconnectedness among institutions, which exacerbates financial system risks.

Recapitalization: While the purpose of the EBA 2011 stress test was to assess the solvency of individual banks as well as the resilience of the EU banking system, the EBA 2014 stress test exercise focuses on the recapitalization of EU banks, i.e., to repair banks' balance sheets by "identifying and implementing necessary corrective action" (ECB, 2013). ECB (2014) states that capital shortfalls have to be covered by raising capital; selling assets should be the exception, and be "distinct from normal operations." This is a positive development since stress tests in 2011, as well as the capitalization exercise, required that banks have to meet a specific capital threshold without actually requiring raising capital.

In July 2014, the ECB outlined how national authorities have to address capital shortfalls with reference to the Terms of Reference of the Economic and Financial Affairs Council (ECOFIN Council) published on July 8, 2014 (ECOFIN, 2014). The ECB determined that banks are supposed to use private sources to access capital. Several banks have used opportunities in 2013 and 2014 to raise capital. If the results of the comprehensive assessment are disclosed, it is likely that private market funding will be unavailable for banks with shortfalls. This might be even more problematic if investors are still sceptical as to the solvency problems of these banks. If private funding is not available, public backstops can be used subject to state aid rules and the EU Bank Recovery and Resolution Directive (BRRD), which comes into effect on January 1, 2015. The rules of receiving state aid, and whether or not there needs to be a bail-in and in what form, however, are still unclear. Moreover, there is the question of whether or not there is a Europe-wide public backstop for those countries that cannot afford to recapitalize their banks and whether the European Stability Mechanism (ESM) can eventually be used to provide necessary funding to recapitalize the banks.

It might not only be exceedingly difficult for banks with shortfalls to raise equity themselves, but this problem could also extend to short-term funding markets. The ECB may be forced to continue its unconventional measures and start another LTRO program similar to 2011 to avoid a liquidity crisis. In other words, missing backstop mechanisms increase the likelihood that the comprehensive assessment will be substantially diluted to avoid large capital shortfalls and a disruption of shortterm funding markets.

\footnotetext{
${ }^{18}$ Note that banks using the internal ratings-based (IRB) approach can switch to the standardized approach when calculating capital requirements for sovereign debt. Interestingly, the EBA 2014 stress test explicitly accounts for markto-market losses on sovereign bonds in the available-for-sale (AFS) and held-for-trading (HFT) category by removing the prudential filters over the 2014-2016 period. Based on my analysis using the most recent EBA disclosure data, European banks currently hold a large part of their sovereign bonds in the AFS account. While the treatment in the stress test has to be appreciated, it indicates that the overall regulatory approach as to benefits that are associated with sovereign debt (which is zero risk weights and, importantly, no concentration limits relative to capital) is inconsistent. Recent research emphasizes the economic risks that are associated with sovereign debt, such as regulatory capital arbitrage and moral hazard (Acharya and Steffen, 2014b).
} 


\section{SYSTEMIC RISK AND IMPLICATIONS FOR STRESS TESTING}

\section{Key FindingS}

- Stress tests are microprudential, not macroprudential.

- Static balance sheets are inconsistent with different forms of systemic risk.

- Stress tests should model behavioral effects and how shocks feed from banks to the real sector and back to the financial sector.

- To comprehensively assess systemic risk in macroeconomic stress tests, the scope of the institutions that are analyzed has to be broadened and include other financial institutions, such as insurance firms or hedge funds.

BOX 3. Key Findings: Systemic Risk and Implications for Stress Testing

While European the stress tests in 2010, 2011, and 2014 have a macroprudential objective, the nature of their execution was still microprudential (Greenlaw et al., 2012). Stress tests should not ignore that the financial system "is a system" (Tucker, 2009). This has to be due to both the 20072009 financial crisis and the recent sovereign debt crisis. Unfortunately, however, this concept has not yet been incorporated into the way eurozone banks are regulated.

The EBA and ECB are assessing the risk exposures of banks on an individual level; however, they do not account for feedback effects or linkages between banks, or between banks and other parts of the financial system (i.e., they do not conceptualize "systemic risk" and its effect on banks and the macro economy). ${ }^{19}$ But it is precisely these linkages that might increase the default risk of banks even though they seem to be well capitalized individually. In other words, too much leverage may accumulate in the financial system as a whole, because banks do not internalize externalities associated with their investment and financing decisions. ${ }^{20}$

In this section, I outline the major forms of systemic risk and how banks are affected. I investigate how shocks can propagate through the financial system, as well as how they can simultaneously affect different institutions because of common exposures. I also derive implications of systemic risk for macroprudential stress testing.

\footnotetext{
${ }^{19}$ Several studies highlight that the financial system has become more interconnected. Wagner (2010) documents a substantial increase in correlation of banks' stock returns over the last decade. Acharya and Steffen (2014b) show that European banks loaded up on European sovereign debt because zero risk weights increased the interconnectedness between banks. Cai et al. (2014) find an increase in common exposure to large syndicated corporate loans since the 1990s, not only in the U.S. but also among European and Asian banks. This highlights how global integration of capital markets increases the interconnectedness of financial institutions.

${ }^{20}$ A few researchers investigate how to internalize systemic risk (Babus, 2013; Castiglionesi and Navarro, 2010; Zawadowski, 2013).
} 


\subsection{Systemic Risk and Contagion}

\subsubsection{Contractual contagion or domino effects}

There is a growing literature focusing on banking networks through interbank claims (Gai and Kapadia, 2010; Gai et al., 2011; Haldane and May, 2011; Haldane, 2009). For example, Gai et al. (2011) model a network of banks that are linked together by their interbank claims. They investigate, once a network structure is in place, whether and how an initial shock propagates through the system. If a single bank makes the decision to hoard liquidity, it will become harder for other banks that usually borrow from that bank to meet their own liquidity condition unless they start hoarding themselves. The structure and connectivity of the network determines how this shock spreads and where it stops. Contagion can also spread through deposit contracts (Dasgupta, 2004). Importantly, these domino effects are a consequence of contractual relationships.

\subsubsection{Information contagion}

Information contagion does not rely on contractual relationships. While the common exposures of banks are discussed further below, it is important to note that holdings of similar assets (or asset commonality) exposes banks to the same risk factors, which can lead to information contagion (Allen et al., 2012). They develop a model in which asset commonality increases systemic risk because banks are short-term financed. If short-term investors receive a signal about the solvency of banks, they might decide not to rollover their investments if solvency risks are high. This issue arises because investors only receive signals about bank solvency, not about (opaque) bank assets. ${ }^{21}$

\subsubsection{Fire sale contagion}

Fire sales occur due to the binding constraints of banks, which could be capital requirements or, importantly, constraints by short-term investors, i.e., banks are forced to sell assets to repay investors (Shleifer and Vishny, 2011). Banks' leverage and substantial exposure to short-term funding such as to money market funds make them particularly vulnerable to stops in short-term funding and the necessary deleveraging might start a cascade of liquidations, as well as a further drop in asset prices. A decline in asset prices reduces the net worth of banks, which eventually causes a massive decline in financial intermediation.

An important problem is that those banks that would be natural buyers of these securities usually engage in the same strategies and thus invest in similar assets. As they are overleveraged and most likely have to liquidate these assets themselves, they are not available as buyers. Those market participants that eventually buy the assets value them less, thereby dislocating prices from fundamental values. This is precisely what happened in 2008 following the bankruptcy of Lehman Brothers. Commercial banks, broker-dealers, hedge funds etc. were heavily exposed to short-term funding collateralized with mortgage-backed securities, which used to be safe securities. After the Lehman Brother default, the short-term funding market dried up causing investors that specialized in these securities to sell the assets, which resulted in a massive price decline and losses.

\footnotetext{
${ }^{21}$ Money market mutual funds in the U.S. withdrew their funding from several European banks completely in the fall of 2011 because of concerns about banks' exposure to risky sovereign debt, as well as the solvency of these institutions (Acharya and Steffen, 2014b).
} 
Fire sales have further feedback effects on the real sector and affect the financial system in several different ways.

1. Banks start hoarding cash on their balance sheet or increase deposits with central banks as a precautionary liquidity move (Acharya et al., 2010; Brunnermeier and Sannikov, 2014; Diamond and Rajan, 2011; Holmstrom and Tirole, 1998).

2. Real investments compete with financial assets. If the price of financial assets is low enough, banks might use the scarce balance sheet capacity available to them and invest in financial assets rather than in real assets (He et al., 2010; Shleifer and Vishny, 2010).

3. Banks overinvested in securitized loans before the onset of the crisis to cater to increased investor demand so that they had to deleverage massively during the crisis, which caused a credit crunch (Shleifer and Vishny, 2010).

4. Risk-averse investors irrationally believe that asset prices cannot go down and flee into "safe" assets once they learn that they hold high-risk securities (Gennaioli et al., 2012).

Correlated investments of banks thus can lead to fire sales. Banks tend to leverage and invest too much ex ante because they do not internalize the fire sale externalities generated through deleveraging in a crisis (Stein, 2010).

\subsubsection{Price complexity externalities}

Price complexity externalities are related to fire sale externalities but do not depend on the binding constraints of banks, such as short-term funding (Caballero and Simsek, 2013). Caballero and Simsek (2013) develop a model of complexity in financial networks where complexity is conceptualized through the uncertainty of banks regarding the cross-exposure of other banks in the network. During crises, banks typically become more concerned about the exposure of their counterparties and of the counterparties' counterparties' exposures, etc.

A similar externality occurs at the level of issuance of asset-backed securities (ABS) and it leads to socially insufficient disclosure of information about their risk characteristics, as shown by Pagano and Volpin (2012). Issuers of ABS choose to issue opaque ABS to enhance the liquidity of their primary market at the cost of reducing their secondary market liquidity below the socially efficient level if fire-sale externalities lead investors to underestimate the value of secondary market liquidity relatrive to its social value.

\subsection{Common Exposures}

While idiosyncratic risk is an important concern, the high degree of interconnectedness in the financial system exposes it to common or system-wide shocks (Hellwig, 1995). Relevant macro risk factors are, for example, interest rates, exchange rates or real estate prices. Hellwig $(1995,2014 \mathrm{a})$ provides examples about the roles of common shocks in various financial crises since the $1980 \mathrm{~s}:^{22}$

${ }^{22}$ Hellwig $(1995,2014 a)$ provides a more extensive discussion, as well as further references. 
1. The savings and loan crisis in the U.S. in the 1980s and 1990s was caused by maturity mismatch of the asset and liability side of banks' balance sheets and a shock (i.e., increase) to interest rates.

2. The Asian financial crisis in the 1990s was associated with exchange rate risks.

3. The recent crises in Ireland and Spain were associated with a decline in real estate prices.

4. The 2007-2009 global financial crisis involved a decline in real estate prices, as well as various forms of contagion magnifying the extent of the crisis.

Importantly, these shocks to macro risk factors might be subtler as they are "hidden" in counterparty (credit risk) exposures. For example, over the last few years, banks have developed innovative risk management techniques to hedge certain types of risks through products such as credit default swaps. This was an important catalyst during the 2007-2009 financial crisis. AIG insured virtually all banks' exposure to mortgage-backed securities. While banks' exposure was transformed into counterparty credit risk to AIG, AIG's risk was driven by real estate prices, which increased the correlation among all banks insured by AIG.

\subsection{Implications for stress testing}

Assessing linkages between banks is important for monitoring the stability of the financial system and should be a key component in future macroprudential stress tests. The different forms of systemic risk outlined above and how banks are interconnected and exposed to common shocks have several implications for the design of stress tests.

Empirical measures of asset commonality need to be developed to quantify the extent of portfolio overlap. Cai et al. (2014) investigate this using data from the syndicated loan market in the U.S. since 1989. They construct a novel measure of asset commonality in corporate loans and find an interesting result. While banks diversify though loan syndication and reduce idiosyncratic default risk, asset commonality increases over time, as does systemic risk. They relate their measure to market-based measures of systemic risk such as SRISK, co-movement value-at-risk (CoVaR), and distressed insurance premium (DIP). They show that asset commonality explains differences in systemic risk in the cross-section of banks, particularly during recessions. ${ }^{23}$

The data collected during the AQR exercise should be very valuable to the construction of these measures. The loan market interconnectedness measure developed in Cai et al. (2014) provides a first step in quantifying banks' exposures. Regulators with more detailed data can extend the analyses investigating and monitoring specific industry overlap, common exposures to leveraged loans or, for example, exchange rate risks that might be hidden in these loans.

However, if the exposures to common shocks are hidden as described above, identifying common exposures on banks' balance sheets might be insufficient. How do banks manage their risks? Who are the counterparties and where do the risks eventually accumulate? If the EBA had conducted the same stress test back in 2006 or 2007, would they have identified the key risk factors during the 2007-2009 financial crisis and, importantly, the exposure European banks had towards these factors? This is hard to believe. As a simple example, the tremendous exposure of European banks to AIG would not have been identified. Credit default swaps or other hedge contracts probably

${ }^{23} \mathrm{CoVaR}$ is developed in Adrian and Brunnermeier (2010) and DIP in Huang et al. (2011). 
would not have been disclosed either. Moreover, the scope of the stress tests (as conducted today) is limited to European banks. The financial system, however, not only includes banks, but also insurance companies (such as AIG) and the shadow banking system (such as money market funds, hedge funds, private equity, etc.), which becomes increasingly important. Even though the number of banks that are part of the EBA 2014 stress test has substantially increased since 2010, future stress tests should consider other non-bank financial institutions in their assessment of systemic risk.

Similarly, the static balance sheet assumption that underlies the current EBA 2014 stress test is inconsistent with the different forms of systemic risk and contagion described above. This approach does not account for a deleveraging process of a banking system that has invested too much and accrued too much debt during credit booms. Banks have to rebalance their portfolios, sell assets, and reduce balance sheets. Moreover, securities in available-for-sale or trading portfolios are marked-to-market and price effects will be magnified through fire sale externalities.

Future stress tests should model possible feedback effects from the banking sector to the real sector. As argued above, banks might engage in precautionary liquidity hoarding, which would reduce credit supply to firms and might lead to a credit crunch. A deteriorating economy suggests higher default rates of firms, which will in turn affect the banking sector. Elevated default probabilities increase loss given defaults as well (maybe because collateral becomes less valuable if the usual buyers are not available to purchase the collateral), which increases expected losses, leads to higher impairment charges, and a further reduction in bank equity.

The next section provides alternative macroprudential stress tests that can serve as a benchmark for regulatory stress tests using market data.

\section{ALTERNATIVE STRESS TESTING MODELS USING PUBLIC DATA}

\section{KEY FindingS}

- Stress test scenarios that are based on a large number of risk factors are subject to model misspecification, which indicates that other models would be more appropriate as benchmarks.

- It was not the methodology of the European stress test (EBA 2011) that caused the deficiencies of the tests, but rather the reliance on Basel II risk weights.

- Required capitalization based on a Core Tier 1 ratio as used in the EBA 2011 stress tests is inadequate and does not compare to other (benchmark) stress test models because of the use of risk-weighted assets.

- Market-based stress scenarios can be used to predict possible stress in access to wholesale funding, such as money market funds.

- Stress tests based on market data incorporate externalities associated with systemic risk, a key component that is still missing in regulatory stress tests. 


\subsection{Alternative Macroprudential Stress Test Models}

Given the incentive problems of financial institutions carrying out the comprehensive assessment, as well at the shortcomings of regulatory stress tests, it might be advantageous to have benchmark models against which one can evaluate the outcomes of regulatory assessments. Steffen (2011), Acharya and Steffen (2013), and Acharya et al. (2013) report interesting alternative stress tests using public data. These models have the additional benefit that they do not require the bankspecific and proprietary data that are used in the official U.S. and European stress tests.

One approach to the design of alternative stress scenarios is to use historical episodes to help reveal capital shortfalls during periods of stress. This is the approach followed in Steffen (2011), Acharya and Steffen (2013, 2014a), and Acharya, Schoenmaker, and Steffen (2013). A different approach that also relies on historical data uses the tails of the distributions of specific risk factors. Below I discuss an alternative approach: instead of relying on scenario analysis, one can use "stressed capital ratios." While simple in its approach, this method avoids defining stress scenarios based on historical episodes. Acharya and Steffen (2014a) use this approach to establish an objective benchmark of possible outcomes in the EBA 2014 stress tests. ${ }^{24}$ All these alternative approaches have a macroprudential objective, as they attempt to determine what capital banks would need to withstand a severe financial crisis and avoid a credit crunch in the economy.

Stress scenarios using market-based measures as described above would explicitly incorporate these linkages that analyse capital shortfalls in situations when overall stock market decline is based on tail risk measures.

\subsection{Alternatives to the EBA 2011 Stress Test}

\subsubsection{Steffen (2011) and Acharya and Steffen (2013)}

Steffen (2011) and Acharya and Steffen (2013) develop stress tests using the financial crisis of 2007-2009 as the stress scenario. ${ }^{25}$ One risk factor is key to this model: the marginal expected shortfall (MES). The MES measures the performance of a bank when the market return as a whole (MSCI Europe index) experiences its worst 5\% trading days over a one-year period, building on the theoretical model in Acharya, Shin, and Yorulmazer (2010). MES thus explicitly incorporates the sensitivity of a bank's equity return to the market in the left tail. The model also uses measures of (quasi-) market leverage ${ }^{26}(\mathrm{LVG})$ and $\log$ asset, the natural logarithm of total assets, as input factors.

Acharya, Shin, and Yorulmazer (2010) estimate factor loadings relating realized equity return over the June 2007 to December 2008 period to MES, LVG, and log assets. These loadings are used to map these factors to the financial crisis scenario as of July 2010 and July 2011. Essentially, this

\footnotetext{
${ }^{24}$ As an additional benefit, this approach does not necessarily rely on market data and thus can be applied to privatelyheld banks as well.

${ }^{25}$ In Annex I, I describe the methodology in more detail.

${ }^{26}$ Measured using balance sheet data as Book value of assets - Book value of equity + Market value of equity.
} 
stress test uses a top-down approach, employing industry averages (the factor loadings) to construct a stress scenario. The model can be used to construct a ranking of European banks with the highest expected percentage equity capital decline. Table 1 reports this ranking as of July 2010 (Panel A) and July 2011 (Panel B).

\begin{tabular}{clcclc}
\hline Ranking & $\begin{array}{c}\text { Panel A. Ranking as of July 2010 } \\
\text { Bank }\end{array}$ & MES & Ranking & $\begin{array}{c}\text { Panel B. Ranking as of July 2011 } \\
\text { Bank }\end{array}$ & MES \\
\hline 1 & Allied Irish Banks & $7.73 \%$ & 1 & Irish Life and Permanent & $-0.49 \%$ \\
2 & Irish Life and Permanent & $4.49 \%$ & 2 & Dexia SA & $2.81 \%$ \\
3 & Dexia SA & $4.58 \%$ & 3 & EFG Eurobank Ergasias SA & $2.08 \%$ \\
4 & Credit Agricole SA & $5.27 \%$ & 4 & Credit Agricole SA & $3.17 \%$ \\
5 & Bank of Ireland & $6.17 \%$ & 5 & Piraeus Bank SA & $2.41 \%$ \\
6 & Commerzbank AG & $2.56 \%$ & 6 & Bank of Ireland & $3.17 \%$ \\
7 & ING Groep NV & $5.49 \%$ & 7 & Societe Generale & $3.01 \%$ \\
8 & Natixis & $4.96 \%$ & 8 & Alpha Bank AE & $1.65 \%$ \\
9 & Societe Generale & $5.33 \%$ & 9 & Natixis & $2.92 \%$ \\
10 & KBC Group SA & $5.34 \%$ & 10 & Commerzbank AG & $2.54 \%$ \\
\hline
\end{tabular}

TABLE 1. Top 10 banks with largest (percentage) capital shortfalls: July 2010 vs. July 2011

As of July 2010, the banks in Ireland led the list of financial institutions with the largest expected capital shortfalls. ${ }^{27}$ Ireland requested financial assistance from the European Union, the euromember states, and the International Monetary Fund (IMF) in November 2010; it received an overall support package of $€ 67.5$ billion. $^{28}$

In the 2010 and 2011 shortfall rankings in Table 1, banks in Belgium and France, specifically Dexia SA, Credit Agricole SA, and Societe Generale, moved to the top of Europe's systemic financial institutions. In June 2010, Dexia SA exited the state guarantee program under which it could issue state guaranteed short- and long-term debt. Dexia SA entered the program in October 2008, after it had been bailed out. In October 2011, after having reported $€ 4$ billion in losses largely due to bad investments, such as in peripheral sovereign bonds, the bank was broken up.

Overall, while the 2010 and 2011 stress tests basically gave a free pass to the banks that were most at risk, the alternative stress test (which can be easily implemented at low cost) "correctly" predicted which banks eventually got into trouble. Acharya and Steffen (2013) show that both in 2007 and 2008 as well as in 2010 and 2011, the capital shortfalls of their model were highly correlated with funds used to bailout these banks. Moreover, Acharya and Steffen (2014b) document that U.S. money market funds were completely withdrawing their funds from the French lenders on top of the list in this ranking.

\subsubsection{Acharya et al. (2014)}

Acharya et al. (2014) also use a stress test model based on public market data. Their approach was developed in Acharya et al. (2010) and Brownlees and Engle (2011). The outcome measure "SRISK" is the amount of capital a bank would need to raise in the event of a crisis. SRISK depends on a bank's stock return during a crisis, as well as its market leverage. The stress scenario

\footnotetext{
${ }^{27}$ Irish Life and Permanent (ranked first in the July 2011 ranking) was nationalized in October 2011.

${ }^{28}$ A detailed analysis of the financial assistance package for Ireland and other states is provided on the website in the Economic and Financial Affairs section of the European Commission (http://ec.europa.eu/economy_finance/eu_borrower/ireland/index_en.htm).
} 
they employ defines a crisis as a $40 \%$ global stock market decline over a six-month period. Based on the (historical) co-movement of a bank's equity return and the stock market index, which is called a long-run marginal expected shortfall (LRMES), they estimate the decline in the market value of equity over the simulation period. Moreover, the model specifies a regulatory capital ratio of $8 \%$ in the U.S. and $5.5 \%$ in Europe that has to be met. ${ }^{29}$

They compare the projected losses of the regulatory stress tests in Europe to SRISK, as well as realized losses during the fall of 2011. While the EBA 2011 stress test has been widely criticized because its stress scenarios were too weak or because it did not address sovereign risk adequately, ${ }^{30}$ these authors document that the projected losses from the EBA 2011 stress tests correlate significantly with the realized losses during the severe economic conditions in the fall of 2011.

However, Acharya et al. (2014) find that the actual outcome of the EBA stress tests (i.e., the required capitalization of the banks) was uncorrelated with SRISK, and in terms of magnitude, inadequate and not comparable. This discrepancy arises because the EBA 2011 stress tests use the Core Tier 1 capital ratio (Basel II) as the measure of capitalization. This ratio is defined as core Tier 1 Capital relative to risk-weighted assets. This is problematic as risk weights do not change over time when asset risks change; thus, they do not reflect their actual risk. Zero risk weights on sovereign debt are an important example as banks engage in regulatory arbitrage, building substantial exposure to risky sovereign debt of peripheral countries without holding equity capital (Acharya and Steffen, 2014b). This behavior leads to excessive leverage in the banking system.

They conjecture that forbearance (because banks were not required to raise capital) did not come from the methodology of the stress test; it arose from the use of risk weights when determining the level of capitalization after the losses had been accounted for. Similar to my earlier argument, this result indicates the appropriateness of using multiple models. Market-based stress tests such as those described above do not rely on flawed risk weights and incorporate actual asset risk. Moreover, other measures of bank capitalization should be used that do not rely on risk weight; instead, they should rely on total assets, such as the (Basel III) leverage ratio.

\subsection{An Alternative to the EBA 2014 Stress Test}

Acharya and Steffen (2014a) propose an alternative stress test that can serve as a benchmark for stress tests. As stated above, the advantage of this approach is to use stressed capital ratios and to avoid using historical episodes. Moreover, it is hardly feasible to design stress scenarios that account for all future shocks that might affect a financial system.

To account for potential losses in future stress scenarios, Acharya and Steffen (2014a) employ four stressed capital shortfall measures. The first two measures raise the level of capital requirements, while the remaining two measures (also) account for losses:

1. Book Capital Shortfall: Using book values of equity and assets, the less stringent benchmark is a leverage ratio (book equity/assets) of $4 \%$ and the more stringent benchmark is a $7 \%$ leverage ratio. Haldane (2012) reports that a $4 \%$ capital ratio (7\% for the largest financial

\footnotetext{
${ }^{29}$ The results of this methodology are available on New York University's Volatility Laboratory website (V-Lab) where systemic risk rankings are updated weekly both globally and in the U.S. (see http://Vlab.stern.nyu.edu/).

${ }^{30}$ EBA 2011 considered sovereign risk only in the trading book even though most of these assets were held in the banking book.
} 
institutions) would have been necessary to guard against bank failure during the recent financial crisis.

2. Market Capital Shortfall: Similarly, using the market value of equity and assets, the less stringent benchmark is a leverage ratio (market equity/assets) of $4 \%$ and the more stringent benchmark is a $7 \%$ leverage ratio.

3. SRISK or Capital Shortfall in a Systemic Crisis: Acharya and Steffen (2014a) assume a systemic financial crisis with a global stock market decline of $40 \%$. SRISK is our measure for a bank's capital shortfall in this scenario, assuming a 5.5\% prudential capital ratio with losses estimated using the V-Lab methodology to estimate the downside risk of bank stock returns. ${ }^{31}$ While this scenario and the resulting SRISK measure use market data and market equity (instead of book equity) in determining leverage, the approach is conceptually similar to that of the European stress tests, which is to estimate losses in a stress scenario and determine the capital shortfall between a prudential capital requirement and the remaining equity after losses.

4. Capital Shortfall after Write Down: Acharya and Steffen (2014a) assume that banks have to write down their entire non-performing loan portfolio net of reserves during a severe financial crisis. They account for this write down when calculating the capital shortfall of the banks using the book capital shortfall measures (which are adjusted for the write downs) and comparing them to a threshold of $4 \%$. This shortfall measure is motivated by theory that posits that under-capitalized banks continue to provide funding to unhealthy borrowers to prevent a write down of their loans ("zombie lending") and that a forced write down can ameliorate the zombie lending problem.

Acharya and Steffen (2014a) use a sample of 109 eurozone banks that participate in the comprehensive assessment (41 banks are publicly listed) and for which balance sheet data are available from SNL Financial either as of December 2012 or June 2013. I update the data for this paper and include data as of December 2013, which is the balance sheet date used by the ECB. These data take into account possible capital increases and portfolio rebalancing that occurs after December 2012 or June 2013, respectively. Annex V reports the 120 banks for which balance sheet data are available from SNL Financial. To calculate capital shortfall using market data, I use a subsample of 40 publicly listed banks. ${ }^{32}$

Table 2 reports descriptive statistics about the banks in this sample aggregated at the country level. ${ }^{33}$ The total assets of all banks (reported in million $€$ ) amount to about $€ 22$ billion. While the updated data comprise a larger set of banks compared to that used by Acharya and Steffen (2014a), it is obvious that the deleveraging process substantially decreased the size of the eurozone's banking

\footnotetext{
${ }^{31}$ This capital shortfall measure has been implemented based on Acharya at al. (2012) and Brownlees and Engle (2013). The data are provided by New York University's V-Lab (http://vlab.stern.nyu.edu/welcome/risk/). The theoretical motivation for the measure can be found in Acharya et al. (2010). SRISK has been documented to be a comprehensive measure that includes losses due to both a bank's investments in assets and its exposure to fragile liabilities, which in the current European context relate, respectively, to holdings of peripheral sovereign bonds and (short-term) funding risk, such as U.S. money market fund withdrawals and other wholesale investors (Figure 5).

${ }^{32}$ The Bank of Cyprus was delisted and is no longer part of the sub-sample of publicly listed banks.

${ }^{33}$ The financial characteristics reported in Table 2 are defined as follows. C Tier 1 is the Core equity Tier 1 capital ratio. It is core equity Tier 1 Capital divided by Risk-Weighted Assets (RWA). Equity/Assets is book equity over total assets. IFRS Tier 1 LVG is C Tier 1 Capital divided by total assets minus intangible assets minus derivative liabilities. Tangible Equity/Tangible Assets is defined as book equity minus intangible assets divided by total assets minus intangible assets. RWA/Assets is RWA divided by total assets. Net Impaired Loans/C Tier 1 Capital is the amount of impaired loans net of reserves over Common Tier 1 Capital. Assets are total assets and measured in million euros.
} 
system. Importantly, there is a striking difference between regulatory common Tier 1 Capital ratios (C Tier 1) and book capital ratios. Averages are weighted by asset size. While the average $\mathrm{C}$ Tier 1 ratio is about $12.73 \%$, the average (book) equity-to-asset ratio (Equity/Assets) is only $5.12 \%$. Riskweighted assets can be used to explain this difference. C Tier 1 is defined as Core Tier 1 capital capital divided by risk-weighted assets. The RWA/Assets ratio is $33.49 \%$. In other words, relying exclusively on a regulatory capital ratio to assess the outcome of the stress test, as the ECB is doing, implicitly assumes that they "got the risk weights right", which might be questionable.

\begin{tabular}{|c|c|c|c|c|c|c|c|}
\hline Country & $\begin{array}{l}\text { Number } \\
\text { of Banks }\end{array}$ & C Tier 1 & $\begin{array}{c}\text { IFRS Tier } 1 \\
\text { LVG }\end{array}$ & Equity/Assets & $\begin{array}{c}\text { Tangible } \\
\text { Equity/Tangible } \\
\text { Assets } \\
\end{array}$ & RWA/Assets & Assets \\
\hline France & 11 & $11.22 \%$ & $3.43 \%$ & $4.45 \%$ & $3.79 \%$ & $26.67 \%$ & $6,953,127$ \\
\hline Germany & 24 & $14.40 \%$ & $3.28 \%$ & $4.43 \%$ & $4.02 \%$ & $24.92 \%$ & $4,649,092$ \\
\hline Spain & 16 & $11.40 \%$ & $4.90 \%$ & $6.72 \%$ & $5.39 \%$ & $44.98 \%$ & $3,151,436$ \\
\hline Italy & 15 & $10.49 \%$ & $5.36 \%$ & $6.45 \%$ & $5.52 \%$ & $48.02 \%$ & $2,361,707$ \\
\hline Netherlands & 7 & $17.05 \%$ & $4.83 \%$ & $3.91 \%$ & $3.79 \%$ & $33.02 \%$ & $1,957,744$ \\
\hline Belgium & 5 & $15.85 \%$ & $4.67 \%$ & $3.79 \%$ & $3.58 \%$ & $25.71 \%$ & 721,652 \\
\hline Austria & 6 & $11.17 \%$ & $5.66 \%$ & $7.71 \%$ & $6.92 \%$ & $53.74 \%$ & 474,248 \\
\hline Finland & 3 & $16.29 \%$ & $4.51 \%$ & $4.54 \%$ & $4.22 \%$ & $23.50 \%$ & 432,422 \\
\hline Greece & 4 & $12.43 \%$ & $5.85 \%$ & $8.27 \%$ & $7.61 \%$ & $61.25 \%$ & 354,223 \\
\hline Ireland & 4 & $13.09 \%$ & $7.29 \%$ & $8.83 \%$ & $8.65 \%$ & $55.13 \%$ & 328,384 \\
\hline Portugal & 4 & $12.53 \%$ & $7.49 \%$ & $6.11 \%$ & $5.85 \%$ & $59.19 \%$ & 318,278 \\
\hline Luxembourg & 5 & $15.52 \%$ & $4.18 \%$ & $7.62 \%$ & $7.02 \%$ & $23.88 \%$ & 96,388 \\
\hline Cyprus & 3 & $10.58 \%$ & $6.78 \%$ & $8.12 \%$ & $7.79 \%$ & $67.51 \%$ & 41,288 \\
\hline Slovakia & 3 & $18.07 \%$ & $8.96 \%$ & $11.26 \%$ & $10.63 \%$ & $50.64 \%$ & 32,724 \\
\hline Slovenia & 3 & $12.05 \%$ & $5.02 \%$ & $10.55 \%$ & $10.18 \%$ & $74.36 \%$ & 21,260 \\
\hline Estonia & 2 & $35.17 \%$ & $16.69 \%$ & $19.94 \%$ & $19.91 \%$ & $47.27 \%$ & 13,375 \\
\hline Malta & 2 & $10.67 \%$ & $5.34 \%$ & $7.70 \%$ & $7.00 \%$ & $49.44 \%$ & 12,979 \\
\hline Latvia & 3 & $19.46 \%$ & $10.26 \%$ & $13.02 \%$ & $12.92 \%$ & $58.10 \%$ & 12,642 \\
\hline Total & 120 & $12.73 \%$ & $4.24 \%$ & $5.19 \%$ & $4.54 \%$ & $33.93 \%$ & $21,932,969$ \\
\hline
\end{tabular}

TABLE 2. Sample of ECB Stress Test Banks: Descriptive Statistics

\subsubsection{Cross-country capital shortfalls using book and market stressed capital ratios}

Tables 3 and 4 report capital shortfalls (in million euros) using stressed book and market capital ratios. Table 3 uses Equity/Assets, as well as Tangible Equity/Tangible Assets (both book capital ratios), and thus the full sample of 120 publicly listed and private banks. The book capital shortfall estimates indicate a capital shortfall for all banks of between $€ 53$ billion and $€ 88$ billion (4\% benchmark capital ratio) or between $€ 451$ billion and $€ 571$ billion (7\% capital ratio).

\begin{tabular}{lcccc}
\hline Country & $\begin{array}{c}\text { Shortfall Assuming a 4\% } \\
\text { Equity/Assets }\end{array}$ & $\begin{array}{c}\text { Threshold } \\
\text { Tangible Equity/ } \\
\text { Tangible Assets }\end{array}$ & $\begin{array}{c}\text { Shortfall Assuming a 7\% Threshold } \\
\text { Equity/Assets }\end{array}$ & $\begin{array}{c}\text { Tangible Equity/ } \\
\text { Tangible Assets }\end{array}$ \\
\hline France & 21,170 & 38,756 & 178,904 & 222,849 \\
Germany & 14,819 & 29,368 & 130,687 & 148,899 \\
Spain & 964 & 1,140 & 18,274 & 50,336 \\
Italy & 1,972 & 3,296 & 20,079 & 36,328 \\
Netherlands & 5,406 & 6,075 & 60,690 & 62,831 \\
Belgium & 6,395 & 6,707 & 23,175 & 24,684 \\
Austria & 0 & 0 & 242 & 1,735 \\
Finland & 2,676 & 2,772 & 11,819 & 12,508 \\
Greece & 0 & 0 & 908 & 2,636 \\
Ireland & 0 & 0 & 1,629 & 2,063 \\
Portugal & 4 & 245 & 4,226 & 4,640 \\
Luxembourg & 0 & 0 & 145 & 830 \\
Cyprus & 0 & 0 & 0 & 159 \\
Slovakia & 0 & 0 & 0 & 0 \\
Slovenia & 0 & 0 & 0 & 0 \\
Estonia & 0 & 0 & 0 & 0 \\
Malta & 0 & 0 & 43 & 58 \\
Latvia & 0 & 0 & & 48 \\
\hline
\end{tabular}


Table 4 reports capital shortfalls in the sub-sample of the 40 publicly listed banks using stressed Equity/Assets and Market Equity/Assets ratios. Market Equity is the bank's market capitalization as of December 31, 2013. The market capital shortfall estimates indicate a capital shortfall of $€ 118$ billion ( $4 \%$ benchmark capital ratio) or $€ 412$ billion ( $7 \%$ capital ratio) for the 40 publicly listed banks.

\begin{tabular}{lccccc}
\hline Country & $\begin{array}{c}\text { Equity/ } \\
\text { Assets }\end{array}$ & $\begin{array}{c}\text { Equity/ } \\
\text { Assets }\end{array}$ & $\begin{array}{c}\text { Market Equity/ } \\
\text { Assets }\end{array}$ & $\begin{array}{c}\text { Market Equity/ } \\
\text { Assets }\end{array}$ & SRISK \\
\hline France & $\mathbf{4 \%}$ & $\mathbf{7 \%}$ & $\mathbf{4 \%}$ & $\mathbf{7 \%}$ & $\mathbf{5 . 5 \%}$ \\
Italy & 13,586 & 127,829 & 55,168 & 191,142 & 189,042 \\
Germany & 1,844 & 18,750 & 11,746 & 69,272 & 76,287 \\
Spain & 9,490 & 69,931 & 40,422 & 106,049 & 102,406 \\
Belgium & 0 & 1,491 & 0 & 13,576 & 37,914 \\
Greece & 4,958 & 14,024 & 8,719 & 15,500 & 26,616 \\
Ireland & 0 & 908 & 28 & 2,345 & 4,360 \\
Austria & 0 & 1,629 & 0 & 1,688 & 3,053 \\
Portugal & 0 & 242 & 329 & 4,040 & 6,677 \\
Malta & 4 & 3,147 & 2,008 & 7,998 & 7,203 \\
Slovakia & 0 & 0 & 0 & 0 & 0 \\
Cyprus & 0 & 0 & 0 & 0 & 0 \\
\hline Total & 0 & 93 & 16 & 202 & 167 \\
\hline TABLE & 29,883 & 238,044 & 118,435 & 411,814 & 453,724 \\
\hline
\end{tabular}

TABLE 4. Capital Shortfalls Using Book and Market Capital Shortfalls

Capital shortfalls based on stressed book capital ratios are a useful benchmark as they do not rely on specific historical scenarios and, importantly, do not rely on risk weights. The results based on stressed market capital ratios incorporate other possible scenarios (that may not have presented themselves in the past) and account for the externalities associated with various forms of systemic risk described in the previous section that are not reflected in book capital ratios. The shortfall differences (e.g., $€ 238$ billion vis-à-vis $€ 412$ billion) indicate that these externalities might (still) be substantial, resulting in too much investment (particularly in asset classes with very low and, unfortunately, static risk-weights) and eventually too much leverage in the banking sector.

\subsubsection{Ranking banks with largest capital shortfalls using SRISK}

Using SRISK instead of market equity/asset ratios to calculate capital shortfalls indicates a shortfall of $€ 454$ billion, which is very similar to using a stressed market equity/asset ratio of $7 \%$ (Table 4). Annex VI is a list of publicly traded banks sorted by SRISK. Three of the top five banks with the highest expected capital shortfall in a systemic crisis are from France, with Credit Agricole listed first with an expected shortfall of $€ 82$ billion. Deutsche Bank has the second largest expected shortfall ( $€ 77$ billion), followed by BNP Paribas with $€ 58$ billion.

Consistent with Table 4, ranking banks from the highest to the lowest expected capital shortfall using SRISK and stressed market equity/asset capital ratios (7\%) shows a rank correlation of 0.92 .

\subsection{3. $\quad$ Assessing Losses Based on Write Downs of Non-Performing Loans}


A final test to calculate capital shortfalls combines "losses" and stressed book capital ratios. To conceptualize this, Acharya and Steffen (2014a) record the amount of non-performing loans (NPLs) of the 120 banks in our sample and assume that all NPLs, which have not previously been provisioned for, are entirely written down. We use $4 \%$ stressed book capital ratios and a C Tier 1 ratio with an $8 \%$ threshold similar to the requirements in the $A Q R$ and the baseline scenario of the stress test. Table 5 reports the shortfalls in million euros. Incorporating NPL losses demonstrates capital shortfalls ranging from $€ 280$ billion (C Tier 1) to $€ 389$ billion (Tangible Equity/Tangible Assets).

\begin{tabular}{lcccc}
\hline & C Tier 1 & Equity/Assets & $\begin{array}{c}\text { Tangible } \\
\text { Equity/Tangible Assets }\end{array}$ & IFRS Tier1 LVG \\
\hline Threshold & $\mathbf{8 \%}$ & $\mathbf{4 \%}$ & $\mathbf{4 \%}$ & $\mathbf{4 \%}$ \\
\hline France & $\mathbf{A Q R}$ & 32,691 & 69,385 & 80,435 \\
Germany & 1,917 & 41,658 & 59,171 & 39,619 \\
Spain & 13,045 & 40,534 & 57,426 & 61,790 \\
Italy & 54,530 & 90,200 & 113,967 & 119,711 \\
Netherlands & 126,740 & 7,080 & 7,356 & 4,287 \\
Belgium & 668 & 11,407 & 12,920 & 6,241 \\
Austria & 2,638 & 0 & 0 & 74 \\
Finland & 1,769 & 3,814 & 3,911 & 2,191 \\
Greece & 0 & 35,207 & 36,184 & 36,468 \\
Ireland & 43,490 & 14,697 & 15,270 & 21,859 \\
Portugal & 23,745 & 5,535 & 6,201 & 1,331 \\
Luxembourg & 2,481 & 0 & 0 & 221 \\
Cyprus & 0 & 3,749 & 3,920 & 4,326 \\
Slovakia & 5,205 & 0 & 0 & 0 \\
Slovenia & 0 & 3,012 & 3,087 & 3,420 \\
Estonia & 3,933 & 0 & 0 & 0 \\
Malta & 0 & 41 & 128 & 0 \\
Latvia & 202 & 0 & 0 & 0 \\
\hline & 0 & 289,623 & 388,925 & 382,176 \\
\hline TABLE 5. Write Down & 280,364 & & & \\
\hline
\end{tabular}

As shown in Table 5, banks in Spain and Italy appear to have the largest capital shortfalls when non-performing assets are fully written down. Both countries account for about a third of the total shortfall after write downs. These results emphasize the importance of the AQR as to the identification (and removal) of non-performing legacy assets using a unified regulatory framework.

\subsubsection{Comparing shortfalls based on regulatory and book (or market) stressed capital ratios}

A crucial weakness of the previous EBA stress tests was the exclusive use of a regulatory capital ratio to assess the capitalization of European banks. As described above, the EBA and ECB again use the $\mathrm{C}$ Tier 1 ratio as the single leverage ratio both in the AQR and stress test.

Acharya and Steffen (2014a) compare the expected capital shortfalls of their sample banks incorporating losses from write downs of NPLs using the regulatory C Tier 1 capital ratio and SRISK and rank banks based on both shortfall measures. Similarly, here I compare SRISK and shortfalls based on stressed book equity/asset ratios. While the rank correlation is -0.15 using the regulatory capital ratio, it is 0.92 using book capital measures (using either $4 \%$ or $7 \%$ thresholds). Figure 2 shows absolute shortfalls under both measures. 

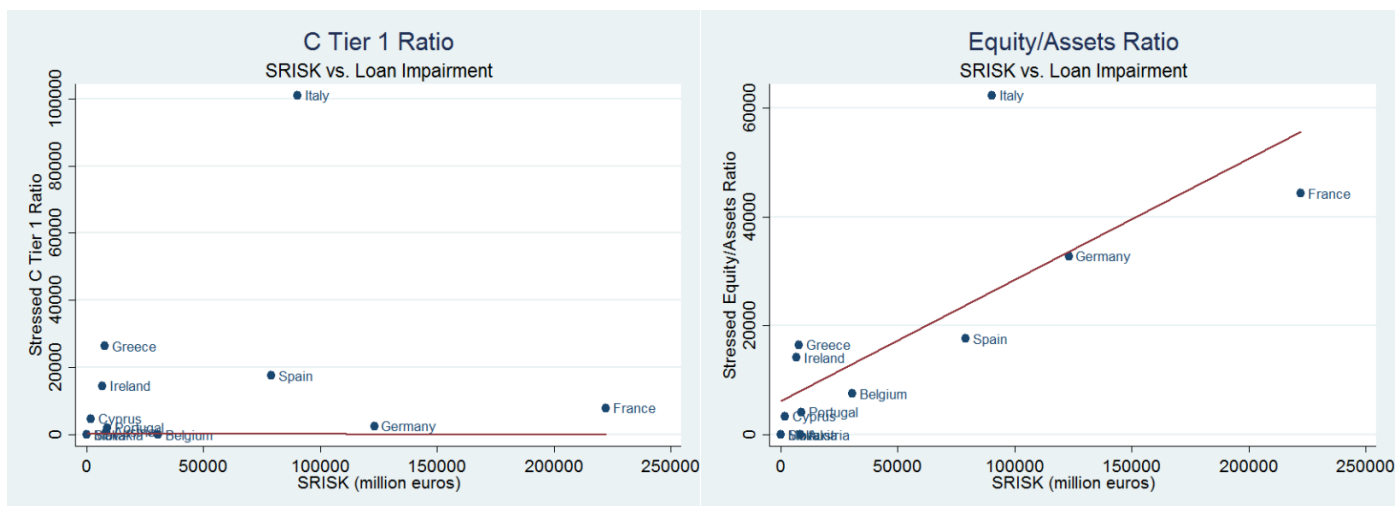

FIGURE 2. Correlation of Capital Shortfalls

These striking results reinforce two important points I made above: First, regulatory capital ratios that rely on risk-weighted assets are not useful measures of capital adequacy of banks as poorly designed risk weights lead to excessive investment and leverage in the financial system. Second, multiple leverage ratios, which do not rely on risk weights, including those based on market prices, are useful to detect a build-up of leverage. Similar to, for example, the CCAR of 2014, multiple leverage ratios should be used in future macroprudential stress tests.

\section{CONCLUSION}

Beginning in November 2014, the ECB will effectively undertake also the role as regulator in charge of the Single Supervisory Mechanism (SSM) of 128 banks in the eurozone. In preparation for commencing regulatory oversight, the ECB conducted a comprehensive assessment of these banks, which included an asset quality review (AQR) and a stress test. The credibility of the ECB might be severely damaged if some banks fail because of legacy assets soon after its oversight begins. The comprehensive assessment was thus necessary to clean up banks' balance sheets before its regulatory responsibilities begin.

The fundamental question is: How will the financial condition of these banks be assessed before the ECB commences its regulatory tasks? And, can the comprehensive assessment lead to a full repair of banks' balance sheets so that the ECB takes over financially sound banks? The answers provided here to these two questions are that the design of the assessment is likely not to have comprehensively dealt with the problems in the banking sector and that risks are likely to remain on the balance sheets that still pose substantial risks to financial stability in the region.

The ECB faces a trade-off: On the one hand, it wants to maintain its reputation as a central bank, while building its standing as an effective financial regulator by comprehensively identifying and valuing the problem assets. On the other hand, there may be looming capital shortfalls that the comprehensive assessment did not identify, with no clearly defined backstops to ameliorate the shortfalls. Worse, national regulators may be faced with incentives that induce them to not to fully disclose problem assets to the ECB. Unless there is full disclosure by the national regulators, the ECB will not be able to making regulatory decisions based on valid information as their comprehensive assessment was not based on complete information. The trade-off potentially weakens the significance of both the AQR and the stress test exercise. 
Stress tests are supposed to be part of the macroprudential regulation of banks. However, regulators have yet to realize that the financial system is a "system" and incorporate this concept into the way they regulate banks. Banks are increasingly interconnected through contractual relationships, as well as exposures to similar assets and similar macroeconomic shocks. Because they do not internalize the risks their behavior creates for the entire financial system, they invest too much and accrue too much leverage. The comprehensive assessment does not account for this "systemic" risk.

Taken together, the trade-off faced by the ECB as well as the omission of systemic risk suggests that the ECB may not be able to reach its objective to identify the problem assets and cleanup the balance sheets of 128 eurozone banks before beginning its regulatory responsibilities, thereby putting its reputation in danger and leaving the financial system in a vulnerable state. The ECB may thus have to continue providing assistance to banks whose solvency is questionable. Importantly, a sustainable growth path still eludes the eurozone countries and the results in this report further increase doubts that the eurozone can escape this low-growth environment in the near future.

In this report, I describe alternative stress test models that rely on public data and account for systemic risk. These models have generated results consistent with economic developments in 2010 and 2011 and provide interesting results using the sample of the banks that take part in the ECB's 2014 comprehensive assessment. These models can serve as a credible benchmark for future comprehensive assessments. 


\section{REFERENCES}

Acharya, V., Engle, R., Pierret, D., 2014. Testing macroprudential stress tests: The risk of regulatory risk weights. J. Monet. Econ. 65, 36-53. doi:10.1016/j.jmoneco.2014.04.014

Acharya, V. V., Engle, R., Richardson, M., 2012. Capital Shortfall: A New Approach to Ranking and Regulating Systemic Risks. Am. Econ. Rev. 102, 59-64. doi:10.1257/aer.102.3.59

Acharya, V. V., Schoenmaker, D., Steffen, S., 2013. How much capital do European banks need? Some estimates. VoxEu.

Acharya, V. V., Shin, H.S., Yorulmazer, T., 2010. Crisis Resolution and Bank Liquidity. Rev. Financ. Stud. 24, 2166-2205. doi:10.1093/rfs/hhq073

Acharya, V. V., Steffen, S., 2013. Analyzing Systemic Risk of the European Banking Sector, in: Fouque, J.P., Langsam, J. (Eds.), Handbook on Systemic RIsk. Cambridge University Press.

Acharya, V. V., Steffen, S., 2014a. Falling Short of Expectations? Stress-Testing the European Banking System. Econ. Policy, CEPS Policy Briefs.

Acharya, V. V., Steffen, S., 2014b. The "Greatest" Carry Trade Ever? Understanding Eurozone Bank Risks. J. financ. econ. forthcomin.

Adrian, T., Brunnermeier, M.K., 2009. CoVaR. SSRN Electron. J. doi:10.2139/ssrn.1269446

Allen, F., Babus, A., Carletti, E., 2012. Asset commonality, debt maturity and systemic risk. J. financ. econ. 104, 519-534. doi:10.1016/j.jfineco.2011.07.003

Babus, A., 2013. The Formation of Financial Networks. SSRN Electron. J. doi:10.2139/ssrn.939754

Brownlees, C.T., Engle, R.F., 2011. Volatility, Correlation and Tails for Systemic Risk

Measurement. SSRN Electron. J. doi:10.2139/ssrn.1611229

Brunnermeier, M.K., Sannikov, Y., 2014. A Macroeconomic Model with a Financial Sector $\dagger$. Am. Econ. Rev. 104, 379-421. doi:10.1257/aer.104.2.379

Caballero, R.J., Simsek, A., 2013. Fire Sales in a Model of Complexity. J. Finance 68, 2549-2587. doi:10.1111/jofi.12087

Cai, J., Saunders, A., Steffen, S., 2012. Syndication, Interconnectedness, and Systemic Risk. SSRN Electron. J. doi:10.2139/ssrn.1508642

Castiglionesi, F., Navarro, N., 2010. Optimal Fragile Financial Networks. Work. Pap.

Dasgupta, A., 2004. Financial Contagion Through Capital Connections: A Model of the Origin and Spread of Bank Panics. J. Eur. Econ. Assoc. 2, 1049-1084. doi:10.1162/1542476042813896

Diamond, D.W., Rajan, R.G., 2011. Fear of Fire Sales, Illiquidity Seeking, and Credit Freezes. Q. J. Econ. 126, 557-591. doi:10.1093/qje/qjr012 
EBA, 2011a. Results of the 2011 EU-wide stress test [WWW Document]. URL http://www.eba.europa.eu/risk-analysis-and-data/eu-wide-stress-testing/2011/results

EBA, 2011b. 2011 EU-Wide Stress Test: Methodological Note [WWW Document]. URL https://www.eba.europa.eu/documents/10180/15932/EBA-ST-2011-004-Detailed-MethodologicalNote_1.pdf

EBA, 2014. Methodological note EU-wide Stress Test 2014 [WWW Document]. URL https://www.eba.europa.eu/documents/10180/669262/Methodological+Note.pdf

EC, 2014. European Commission projections for the 2014 EU-wide stress tests baseline scenario [WWW Document]. URL https://www.eba.europa.eu/documents/10180/669262/EC+projections.pdf

ECB, 2013. Note Comprehensive Assessment - October 2013 [WWW Document]. URL http://www.ecb.europa.eu/pub/pdf/other/notecomprehensiveassessment201310en.pdf?065ff895321 3aaf23e385c1119dd541a

ECB, 2014a. Comprehensive Assessment Stress Test Manual [WWW Document]. URL http://www.ecb.europa.eu/pub/pdf/other/castmanual201408en.pdf

ECB, 2014b. Asset Quality Review - Phase 2 Manual [WWW Document]. URL http://www.ecb.europa.eu/pub/pdf/other/assetqualityreviewphase2manual201403en.pdf?e8cc41ce0e 4ee40222cbe148574e4af7

ECB, 2014c. Note on the Comprehensive Assessment - February 2014 [WWW Document]. URL http://www.ecb.europa.eu/pub/pdf/other/notecomprehensiveassessment201402en.pdf?120cf5522a7 9fe 53cd30a54aaf34f55d

ECOFIN, 2014. Terms of Reference - Applicable rules on addressing capital shortfalls and burden sharing in the context of the Asset Quality Review and Stress Tests [WWW Document]. URL http://www.consilium.europa.eu/uedocs/cms_data/docs/pressdata/en/ecofin/143781.pdf

ESRB, 2014. EBA/SSM stress test: The macroeconomic adverse scenario [WWW Document]. URL https://www .eba.europa.eu/documents/10180/669262/2014-0429_ESRB_Adverse_macroeconomic_scenario_-_specification_and_results_finall_version.pdf

Fed, 2013a. Comprehensive Capital Analysis and Review 2014: Summary Instructions and Guidance. [WWW Document]. URL http://www.federalreserve.gov/newsevents/press/bcreg/bcreg20131101a2.pdf

Fed, 2013b. Comprehensive Capital Analysis and Review 2014: Assessment Framework and Results [WWW Document]. URL http://www.federalreserve.gov/newsevents/press/bcreg/ccar2013-results-20130314.pdf

Fed, 2014. Dodd-Frank Act Stress Test 2014: Supervisory Stress Test Methodology and Results [WWW Document]. URL

http://www.federalreserve.gov/newsevents/press/bcreg/bcreg20140320a1.pdf 
Gai, P., Haldane, A., Kapadia, S., 2011. Complexity, concentration and contagion. J. Monet. Econ. 58, 453-470. doi:10.1016/j.jmoneco.2011.05.005

Gai, P., Kapadia, S., 2010. Contagion in financial networks. Proc. R. Soc. A Math. Phys. Eng. Sci. 466, 2401-2423. doi:10.1098/rspa.2009.0410

Gennaioli, N., Shleifer, A., Vishny, R., 2012. Neglected risks, financial innovation, and financial fragility. J. financ. econ. 104, 452-468. doi:10.1016/j.jfineco.2011.05.005

Haldane, A.G., 2009. Rethinking the Financial Network, in: Speech at the Financial Student Association, Amsterdam, 28 April. Amsterdam.

Haldane, A.G., May, R.M., 2011. Systemic risk in banking ecosystems. Nature 469, 351-5. doi:10.1038/nature09659

He, Z., Khang, I.G., Krishnamurthy, A., 2010. Balance Sheet Adjustments during the 2008 Crisis. IMF Econ. Rev. 58, 118-156. doi:10.1057/imfer.2010.6

Hellwig, M.F., 1995. Systemic Aspects of Risk Management in Banking and Finance. Swiss J. Econ. Stat. 131, 723-737.

Hellwig, M.F., 2014a. Systemic Risk and Macro-Prudential Policy. Speech Ned. Bank's HighLevel Semin. "Making Macroprudent. Policy Work Pract.

Hellwig, M.F., 2014b. Yes Virginia, There is a European Banking Union! But It May Not Make Your Wishes Come True. Max Planck Inst. Res. Collect. Goods 2014/12.

Hellwig, M.F., 2014c. Financial Stability, Monetary Policy, Banking Supervision, and Central Banking. Max Planck Inst. Res. Collect. Goods 2014/12.

Holmstrom, B., Tirole, J., 1998. Private and Public Supply of Liquidity. J. Polit. Econ. 106, 1-40.

Huang, X., Zhou, H., Zhu, H., 2009. A framework for assessing the systemic risk of major financial institutions. J. Bank. Financ. 33, 2036-2049. doi:10.1016/j.jbankfin.2009.05.017

Pagano, M., Volpin, P., 2012. Securitization, Transparency and Liquidity , Review of Financial Studies , 2012, 25, 2417-2453.

Schoenmaker, D., 2013. The State of the Financial Sector in Europe. Working Paper. Duisenberg School of Finance, Amsterdam.

Shleifer, A., Vishny, R., 2011. Fire Sales in Finance and Macroeconomics. J. Econ. Perspect. 25, 29-48. doi:10.1257/jep.25.1.29

Shleifer, A., Vishny, R.W., 2010. Unstable Banking. J. financ. econ. 97, 306-318.

Steffen, S., 2011. Measuring systemic risk of the European banking sector. VoxEu.

Stein, J.C., 2010. Monetary Policy as Financial-Stability Regulation. NBER Work. Pap. 
Tucker, P., 2009. The Debate on Financial System resilience: Macroprudential Instruments. Barclays Annu. Lect.

Wagner, W., 2010. Diversification at financial institutions and systemic crises. J. Financ. Intermediation 19, 373-386. doi:10.1016/j.jfi.2009.07.002

Zawadowski, A., 2013. Entangled Financial Systems. SSRN Electron. J. doi:10.2139/ssrn.1765993 


\section{ANNEXES}

\section{Annex I. Comparing EBA 2011 and EBA 2014}

\section{General Setup/Information}

\begin{tabular}{ll}
\hline Dimension & EBA 2011 \\
\hline Scope & 91 banks from 21 EU member \\
& states, at highest level of \\
& consolidation; covers at least 50\% \\
& per EU state as of end of 2011; \\
& insurance activities excluded
\end{tabular}

\section{Authorities behind the tests}

Stress test conducted by EBA in coordination with NCAs, ESRB, $\mathrm{ECB}$, and EC; NCAs conducted on national level; QA by NCAs/ECB and EBA; dissemination of final results by EBA

\begin{tabular}{|c|c|c|}
\hline $\begin{array}{l}\text { Centralized } \\
\text { exercise? }\end{array}$ & $\begin{array}{l}\text { Guidelines for testing developed } \\
\text { by EBA and ECB, and "agreed by } \\
\text { all participants" }\end{array}$ & $\begin{array}{l}\text { Common methodology published by EBA, } \\
\text { based on common agreement on the scenarios, } \\
\text { methodology, and templates by EBA, NCAs, } \\
\text { and ECB }\end{array}$ \\
\hline Intention & $\begin{array}{l}\text { Assessment of individual banks' } \\
\text { solvency plus resilience of the } \\
\text { entire EU banking system }\end{array}$ & $\begin{array}{l}\text { Enhance transparency, induce repair, and } \\
\text { increase confidence building }\end{array}$ \\
\hline Disclosure & $\begin{array}{l}\text { Detailed methodology, but } \\
\text { allowing for much discretion; } \\
\text { detailed disclosure of results, up to } \\
3,400 \text { data points (vs. } 149 \text { in } 2010 \text { ) } \\
\text { released per bank }\end{array}$ & $\begin{array}{l}\text { Detailed methodology; higher degree of } \\
\text { standardization than in 2011; amount of } \\
\text { disclosure of results not yet known, but likely } \\
\text { very detailed }\end{array}$ \\
\hline $\begin{array}{l}\text { Learning from past } \\
\text { stress tests? }\end{array}$ & $\begin{array}{l}\text { Lessons learned" analysis } \\
\text { conducted by EBA and NCAs } \\
\text { following the } 2010 \text { exercise }\end{array}$ & $\begin{array}{l}\text { (Not publicly made known if such an exercise } \\
\text { has been conducted) }\end{array}$ \\
\hline $\begin{array}{l}\text { Bottom-up } \\
\text { approach }\end{array}$ & $\begin{array}{l}\text { Banks employ their own models to } \\
\text { translate common scenarios into } \\
\text { balance sheets and P\&L } \\
\text { statements, based on the unified } \\
\text { methodology; stepwise quality } \\
\text { assurance by NCAs and } \\
\text { EBA/ECB; publication of results } \\
\text { by EBA; measures to address } \\
\text { vulnerabilities put forth by EU } \\
\text { member states }\end{array}$ & $\begin{array}{l}\text { Similar format; new features: QA assurance } \\
\text { transferred to NCAs/ECB only }\end{array}$ \\
\hline $\begin{array}{l}\text { Discretionary } \\
\text { interpretation of } \\
\text { rules }\end{array}$ & $\begin{array}{l}\text { Lack of truly centralized rules for } \\
\text { stress testing; general methodology } \\
\text { allowing for discretionary } \\
\text { interpretation by NCAs }\end{array}$ & $\begin{array}{l}\text { Trend towards unified metholodogy (i.e., NPLs, } \\
\text { loan forbearance), but still large discretion with } \\
\text { banks using their own models }\end{array}$ \\
\hline Exemptions & $\begin{array}{l}\text { Refusal of result publication for } \\
\text { some banks (e.g., German Helaba) }\end{array}$ & $\begin{array}{l}\text { Exemption from adverse scenario for Franco- } \\
\text { Belgian Dexia }\end{array}$ \\
\hline
\end{tabular}

EBA 2014

124 EU banks (104 SSM, 20 non-SSM) from 22 EU member states, at highest level of consolidation; covers at least $50 \%$ per EU state as of the end of 2013; eurozone banks: value of assets $>€ 30$ billion or $>€ 5$ billion and $>20 \%$ of the GDP of host country; insurance activities are excluded

Stress test conducted by EBA in coordination with NCAs, ESRB, ECB, and EC; NCAs (including ECB), conducted on national level, are responsible for QA and supervisory reaction measures; dissemination of final results by EBA; dissemination of additional sensitivities by NCAs and ECB; Comprehensive assessment conducted by ECB in coordination with national NCAs; dissemination of final results of overall comprehensive assessment by ECB .

Common methodology published by EBA, based on common agreement on the scenarios, methodology, and templates by EBA, NCAs, and ECB

Enhance transparency, induce repair, and

Detailed methodology; higher degree of standardization than in 2011; amount of disclosure of results not yet known, but likely very detailed

(Not publicly made known if such an exercise Similar format; new features: QA assurance transferred to NCAs/ECB only Belgian Dexia 
General Modeling Choice

\begin{tabular}{lll}
\hline Dimension & EBA 2011 & EBA 2014 \\
\hline $\begin{array}{l}\text { Static balance } \\
\text { sheet constraint }\end{array}$ & $\begin{array}{l}\text { Static balance sheet, zero growth, } \\
\text { constant business mix assumptions; } \\
\text { exemptions from static balance sheet } \\
\text { assumption: banks under "any } \\
\text { regulatory imposed decision" }\end{array}$ & $\begin{array}{l}\text { Still static balance sheet approach; tighter } \\
\text { definition on exemptions from static balance } \\
\text { sheet assumption (i.e., only EC-approved } \\
\text { restructuring) }\end{array}$ \\
$\begin{array}{l}\text { Sovereign risk } \\
\text { exposure }\end{array}$ & $\begin{array}{l}\text { Haircuts only applied to bonds in } \\
\text { trading book; haircuts rather small; } \\
\text { no consideration of sovereign default }\end{array}$ & $\begin{array}{l}\text { Haircuts applied to bonds in trading book } \\
\text { and banking book (subject to predefined } \\
\text { prudential filters); small, unrealistic } \\
\text { haircuts; no consideration of sovereign } \\
\text { default }\end{array}$ \\
& $\begin{array}{l}\text { Still no explicit consideration of liquidity } \\
\text { risk; NCAs may introduce additional } \\
\text { indicators, if desired }\end{array}$ \\
& $\begin{array}{l}\text { Liquidity risk is not particularly } \\
\text { assessed, only implicitly through } \\
\text { funding costs; liquidity risk covered } \\
\text { by "specific thematic review" for } \\
\text { "supervisory purposes" }\end{array}$ & \\
\hline
\end{tabular}

\section{Detailed Scenario}

\begin{tabular}{|c|c|c|}
\hline Dimension & EBA 2011 & EBA 2014 \\
\hline $\begin{array}{l}\text { Time horizon } \\
\text { adverse scenario }\end{array}$ & 8 quarters: 2011,2012 & 12 quarters: $2014-2016$ \\
\hline $\begin{array}{l}\text { Reception of } \\
\text { scenario }\end{array}$ & Too weak and lack of consistency & (Not yet known) \\
\hline $\begin{array}{l}\text { General } \\
\text { comments }\end{array}$ & $\begin{array}{l}\text { Designed by EC (baseline scenario) and } \\
\text { ESRB/ECB (adverse scenario); } \\
\text { no adaption of scenarios by NCAs }\end{array}$ & $\begin{array}{l}\text { Designed by EC (baseline scenario) and } \\
\text { ESRB (adverse scenario); NCAs may } \\
\text { extend scenarios by additional sensitivities } \\
\text { and market risk shocks; results published } \\
\text { separately }\end{array}$ \\
\hline $\begin{array}{l}\text { Specific } \\
\text { scenarios }\end{array}$ & $\begin{array}{l}\text { Outline adverse scenario: persistent on- } \\
\text { going sovereign debt crisis; global } \\
\text { negative demand shocks originating in } \\
\text { the U.S.; USD depreciation vs. all } \\
\text { currencies; } \\
\text { EU GDP: }-0.4 \%(2011), 0 \%(2012) \\
\text { (eurozone:-0.5\%, }-0.2 \%) \\
\text { EU inflation: }+1.5 \%(2011),+0.5 \% \\
\text { (2012) } \\
\text { EU unemployment: }+0.3 \%(2011) \text {, } \\
+1.2 \%(2012) ; \\
\text { EU equity prices: }-14 \% \text {, house prices: } \\
\text { [not disclosed]\% }\end{array}$ & $\begin{array}{l}\text { Outline adverse scenario: (i) increase in } \\
\text { global bond yields, (ii) further deterioration } \\
\text { of credit quality in countries with feeble } \\
\text { demand, (iii) stalling policy reforms, (iv) } \\
\text { lack of bank balance sheet repair; } \\
\text { EU GDP: -0.7\% (2014), -3.6\% (2015), - } \\
5.2 \% \text { (2016); } \\
\text { Cumulative deviation of EU unemployment } \\
\text { from baseline level: +0.6\% (2014), }+1.9 \% \\
\text { (2015), } 2.9 \%(2016) \text {; } \\
\text { Equity prices: }-15 \% \text {, house prices: }-8-11 \%\end{array}$ \\
\hline $\begin{array}{l}\text { Sovereign debt } \\
\text { shocks in the } \\
\text { adverse scenario }\end{array}$ & $\begin{array}{l}\text { Flight-to-quality effect: in Q1/2011, } \\
\text { yields on German bonds stay at baseline } \\
\text { level; identical increase of } 75 \text { bps/ } 66 \text { bps } \\
\text { for other eurozone/other EU bonds + } \\
\text { realized volatility of daily changes in } \\
\text { sovereign CDS spreads in November } \\
2010 \text {; from Q2/2011, government rates } \\
\text { remain constant }\end{array}$ & $\begin{array}{l}\text { No flight-to-quality effect: increase of } \\
\text { spreads for all bonds, with some re-opening } \\
\text { of spreads; calibration based on past } \\
\text { correlation structure in August 2012- } \\
\text { December } 2013\end{array}$ \\
\hline
\end{tabular}




\begin{tabular}{lll}
\hline Dimension & EBA 2011 & EBA 2014 \\
$\begin{array}{l}\text { Legal basis for } \\
\text { regulatory ratios }\end{array}$ & $\begin{array}{l}\text { Capital definition as in CRD III (Basel } \\
\text { 2.5); no consideration of CRD IV rules }\end{array}$ & $\begin{array}{l}\text { Capital definition as in CRR/CRD IV (Basel } \\
\text { III); transitional rules as per December } \\
2013 / 2014 / 2015 / 2016\end{array}$ \\
$\begin{array}{l}\text { Regulatory } \\
\text { thresholds }\end{array}$ & $\begin{array}{l}\text { One regulatory ratio considered: CT1 } \\
\text { ratio; 5\% for adverse scenario; } \\
\text { no additional testing by NCAs }\end{array}$ & $\begin{array}{l}\text { One regulatory ratio considered: CET1 ratio; } \\
\text { Hurdle rates: 8\% for baseline scenario, 5.5\% } \\
\text { for adverse scenario; additional thresholds } \\
\text { and tighter requirements possible and } \\
\text { imposed by NCAs }\end{array}$ \\
& &
\end{tabular}

Other Details

\begin{tabular}{lll}
\hline Dimension & EBA 2011 & EBA 2014 \\
\hline $\begin{array}{l}\text { Micro vs. } \\
\text { macroprudential } \\
\text { exercise }\end{array}$ & $\begin{array}{l}\text { Microprudential stress test with focus } \\
\text { on capital adequacy of individual } \\
\text { institutions }\end{array}$ & $\begin{array}{l}\text { A microprudential exercise testing capital } \\
\text { adequacy; additional macroeconomic } \\
\text { considerations }\end{array}$ \\
\hline
\end{tabular}

\section{Recapitalization}

\begin{tabular}{|c|c|c|}
\hline Dimension & EBA 2011 & EBA 2014 \\
\hline $\begin{array}{l}\text { Decision on } \\
\text { recapitalization }\end{array}$ & $\begin{array}{l}\text { No explicit statement on } \\
\text { recapitalizations; "coordinated strategy" } \\
\text { of EU member states }\end{array}$ & $\begin{array}{l}\text { Explicit responsibility for recapitalization in } \\
\text { case of shortfalls with NCAs; no central } \\
\text { recapitalization device }\end{array}$ \\
\hline $\begin{array}{l}\text { Bail-in of private } \\
\text { shareholders }\end{array}$ & No clear call for bail-in & $\begin{array}{l}\text { Potentially central tool "Banking } \\
\text { Communication" (version July 2013) of the } \\
\text { EC explicitly calling for the bail-in of } \\
\text { shareholders and junior debtors; } \\
\text { Uncertainties: No call for state aid, } \\
\text { compliance of member states, or transfer of } \\
\text { power to EC; BRRD only in force from } \\
\text { January 2015; bail-in provisions in January } \\
2016\end{array}$ \\
\hline $\begin{array}{l}\text { Addressing } \\
\text { capital levels }\end{array}$ & Not taken into consideration & No clear communication \\
\hline $\begin{array}{l}\text { Applicability of } \\
\text { hybrid } \\
\text { instruments to } \\
\text { covered } \\
\text { shortfalls }\end{array}$ & $\begin{array}{l}\text { No statement on how capital shortfalls } \\
\text { are to be addressed }\end{array}$ & $\begin{array}{l}\text { AQR and baseline test shortfalls: covered by } \\
\text { CET } 1 \text { capital instruments; adverse scenario: } \\
\text { use of convertible capital possible subject to } \\
\text { limits }\end{array}$ \\
\hline
\end{tabular}

Results

\begin{tabular}{lll}
\hline Dimension & EBA 2011 & EBA 2014 \\
\hline Results & $€ 2.5$ billion shortfall on regulatory & (Not yet known) \\
& $\begin{array}{l}\text { capital, with 8 banks failing (5 from } \\
\text { Spain, two from Greece, 1 from Austria) }\end{array}$ & \\
\hline
\end{tabular}

Source: EBA (2011a, 2011b), EBA (2014), EC (2014), ESRB (2014) 
Annex II. Scenarios in EBA 2014

\begin{tabular}{|c|c|c|c|c|}
\hline & $\begin{array}{l}\text { EBA } 2011 \text { Adverse } \\
(2011 / 2012)\end{array}$ & $\begin{array}{l}\text { Actual Development 2011- } \\
2013\end{array}$ & $\begin{array}{l}\text { Worst } \\
\text { Value } \\
\text { 2011-2013 }\end{array}$ & $\begin{array}{l}\text { EBA } 2014 \text { Adverse } \\
(2014 / 2015 / 2016)\end{array}$ \\
\hline GDP EU & $-0.4 \% / 0.0 \%$ & $1.6 \% /-0.4 \% / 0.1 \%$ & $-0.4 \%$ & $-0.7 \% /-1.4 \% / 0 \%$ \\
\hline GDP Germany & $-0.9 \% / 0.5 \%$ & $3.3 \% / 0.7 \% / 0.4 \%$ & $0.4 \%$ & $-0.9 \% /-2.0 \% / 1.4 \%$ \\
\hline GDP Greece & $-4.0 \% /-1.2 \%$ & $-7.1 \% /-7.0 \% /-3.9 \%$ & $-7.1 \%$ & $-1.6 \% /-0.6 \% / 1.2 \%$ \\
\hline GDP Ireland & $-1.6 \% / 0.3 \%$ & $2.2 \% / 0.2 \% /-0.3 \%$ & $-0.3 \%$ & $-1.3 \% /-0.7 \% / 0.5 \%$ \\
\hline GDP Italy & $-0.1 \% /-1.0 \%$ & $0.4 \% /-2.4 \% /-1.9 \%$ & $-2.4 \%$ & $-0.9 \% /-1.6 \% /-0.7 \%$ \\
\hline GDP Portugal & $-3.0 \% /-2.7 \%$ & $-1.3 \% /-3.2 \% /-1.4 \%$ & $-3.2 \%$ & $-0.8 \% /-2.3 \% /-1.1 \%$ \\
\hline GDP Spain & $-1.1 \% /-0.7 \%$ & $0.1 \% /-1.6 \% /-1.2 \%$ & $-1.6 \%$ & $-0.3 \% /-1.0 \% / 0.1 \%$ \\
\hline Unemployment EU & $10 \% / 10.5 \%$ & $9.6 \% / 10.4 \% / 10.8 \%$ & $10.8 \%$ & $11.3 \% / 12.3 \% / 13.0 \%$ \\
\hline Unemployment & $6.8 \% / 6.9 \%$ & $5.9 \% / 5.5 \% / 5.3 \%$ & $5.9 \%$ & $5.4 \% / 6.0 \% / 7.0 \%$ \\
\hline Germany & $15.2 \% / 16.3 \%$ & $17.7 \% / 24.3 \% / 27.3 \%$ & $27.3 \%$ & $26.5 \% / 25.3 \% / 21.6 \%$ \\
\hline Unemployment Greece & $14.9 \% / 15.8 \%$ & $14.7 \% / 14.7 \% / 13.1 \%$ & $14.7 \%$ & $12.4 \% / 12.9 \% / 14.0 \%$ \\
\hline Unemployment Ireland & $8.6 \% / 9.2 \%$ & $8.4 \% / 10.7 \% / 12.2 \%$ & $12.2 \%$ & $12.9 \% / 13.7 \% / 14.4 \%$ \\
\hline Unemployment Italy & $11.6 \% / 13.0 \%$ & $12.9 \% / 15.9 \% / 16.5 \%$ & $16.5 \%$ & $17.2 \% / 18.2 \% / 17.3 \%$ \\
\hline $\begin{array}{l}\text { Unemployment } \\
\text { Portugal } \\
\text { Unemployment Spain }\end{array}$ & $21.3 \% / 22.4 \%$ & $21.7 \% / 25.0 \% / 26.4 \%$ & $26.4 \%$ & $26.3 \% / 26.8 \% / 27.1 \%$ \\
\hline HICP Inflation EU & $1.5 \% / 0.5 \%$ & $3.1 \% / 2.6 \% / 1.5 \%$ & & $1.1 \% / 0.6 \% / 0.0 \%$ \\
\hline HICP Inflation & $1.6 \% / 1.5 \%$ & $2.5 \% / 2.1 \% / 1.6 \%$ & & $1.4 \% / 0.9 \% / 0.4 \%$ \\
\hline Germany & $2.2 \% /-0.1 \%$ & $3.1 \% / 1.0 \% /-0.9 \%$ & & $-1.0 \% /-0.9 \% /-0.7 \%$ \\
\hline HICP Inflation Greece & $0.1 \% / 0.6 \%$ & $1.2 \% / 1.9 \% / 0.5 \%$ & & $0.7 \% / 0.4 \% / 0.3 \%$ \\
\hline HICP Inflation Ireland & $1.3 \% / 0.8 \%$ & $2.9 \% / 3.3 \% / 1.3 \%$ & & $0.9 \% / 1.0 \% / 0.6 \%$ \\
\hline HICP Inflation Italy & $1.2 \% /-0.3 \%$ & $3.6 \% / 2.8 \% / 0.4 \%$ & & $0.7 \% / 0.1 \% /-0.7 \%$ \\
\hline $\begin{array}{l}\text { HICP Inflation } \\
\text { Portugal } \\
\text { HICP Inflation Spain }\end{array}$ & $0.9 \% /-0.2 \%$ & $3.1 \% / 2.4 \% / 1.5 \%$ & & $0.3 \% / 0.4 \% / 0.8 \%$ \\
\hline Gvt Yields EU & $3.3 \% / 3.5 \%$ & $4.3 \% / 3.7 \% / 3.0 \%$ & $4.3 \%$ & $4.4 \% / 4.3 \% / 4.4 \%$ \\
\hline Gvt Yields Germany & & $2.6 \% / 1.5 \% / 1.6 \%$ & $2.6 \%$ & $2.9 \% / 2.9 \% / 3.0 \%$ \\
\hline Gvt Yields Greece & & $15.8 \% / 22.5 \% / 10.1 \%$ & $22.5 \%$ & $11.2 \% / 10.6 \% / 10.7 \%$ \\
\hline Gvt Yields Ireland & & $9.6 \% / 6.2 \% / 3.8 \%$ & $9.6 \%$ & $4.9 \% / 4.8 \% / 4.9 \%$ \\
\hline Gvt Yields Italy & & $5.4 \% / 5.5 \% / 4.3 \%$ & $5.5 \%$ & $5.9 \% / 5.6 \% / 5.8 \%$ \\
\hline Gvt Yields Portugal & & $10.2 \% / 10.6 \% / 6.3 \%$ & $10.6 \%$ & $7.4 \% / 7.1 \% / 7.2 \%$ \\
\hline Gvt Yields Spain & & $5.4 \% / 5.9 \% / 4.6 \%$ & $5.9 \%$ & $5.7 \% / 5.5 \% / 5.6 \%$ \\
\hline House Prices EU & $(-3.8 \% /-11.6 \%)$ & $0.1 \% /-1.6 \% /-0.9 \%$ & $-1.6 \%$ & $-7.9 \% /-6.2 \% /-2.1 \%$ \\
\hline House Prices Germany & & $1.4 \% / 1.8 \% / \mathrm{NA}$ & $1.4 \%$ & $-4.5 \% /-1.8 \% / 2.3 \%$ \\
\hline House Prices Greece & & $-7.3 \% /-12.5 \% /-8.9 \%$ & $-12.5 \%$ & $-11.1 \% /-9.9 \% /-$ \\
\hline House Prices Ireland & & $-15.4 \% /-11.9 \% / 1.3 \%$ & $-15.4 \%$ & $7.9 \%$ \\
\hline House Prices Italy & & $-2 \% /-5.4 \% /-7.0 \%$ & $-7.0 \%$ & $-3.5 \% /-0.9 \% / 1.4 \%$ \\
\hline House Prices Portugal & & $-7.2 \% /-8.4 \% /-2.2 \%$ & $-8.4 \%$ & $-7.9 \% /-4.7 \% /-3.3 \%$ \\
\hline House Prices Spain & & $-9.9 \% /-16.9 \% /-10.4 \%$ & $-16.9 \%$ & $\begin{array}{l}-9.3 \% /-7.5 \% /-4.6 \% \\
-7.4 \% /-3.0 \% / 0.9 \%\end{array}$ \\
\hline
\end{tabular}

Source: ESRB (2014) 


\section{Annex III. Comparing CCAR 2014 and EBA 2014}

\section{General Setup/Information}

\begin{tabular}{|c|c|c|}
\hline Dimension & CCAR 2014 & EBA 2014 \\
\hline Scope & $\begin{array}{l}\text { Thirty bank holding companies(BHCs) with } \\
\text { more than } \$ 50 \text { billion in total consolidated } \\
\text { assets; }{ }^{34} \text { accounts for approximately } 80 \% \text { of } \\
\text { total banking assets (Board of the Governors } \\
\text { of the Federal Reserve, } 3 \text { March } 2014 \text { ) }\end{array}$ & $\begin{array}{l}124 \text { EU banks from } 22 \text { EU member states, } \\
\text { at highest level of consolidation; } 104 \text { are } \\
\text { SSM banks and } 20 \text { are non-SSM banks, } \\
\text { covering at least } 50 \% \text { per EU state as of } \\
\text { the end of } 2013 \text {; insurance activities are } \\
\text { excluded from balance sheet and P\&L } \\
\text { statement }\end{array}$ \\
\hline $\begin{array}{l}\text { Legal } \\
\text { framework } \\
\text { for stress } \\
\text { testing }\end{array}$ & $\begin{array}{l}\text { Dodd-Frank Wall Street Reform and } \\
\text { Consumer Protection Act; Capital Plan Rule } \\
12 \text { CFR } 225.8\end{array}$ & $\begin{array}{l}\text { Regulation (EU) No 1093/2010 } \\
\text { establishing a European Supervisory } \\
\text { Authority }\end{array}$ \\
\hline Intention & $\begin{array}{l}\text { Increase transparency and enhance market } \\
\text { discipline }\end{array}$ & $\begin{array}{l}\text { Increase transparency, induce } \\
\text { recapitalization, and enhance market } \\
\text { confidence }\end{array}$ \\
\hline $\begin{array}{l}\text { Amount of } \\
\text { disclosure }\end{array}$ & $\begin{array}{l}\text { Very detailed; not disclosing information on } \\
\text { exact modelling choice of the Fed stress } \\
\text { testing }\end{array}$ & Very detailed \\
\hline $\begin{array}{l}\text { Setup of } \\
\text { capital } \\
\text { exercise }\end{array}$ & $\begin{array}{l}\text { Dodd-Frank Act (DFA) stress tests } \\
\text { (supervisory and company basis) and } \\
\text { Comprehensive Capital Analysis and Review } \\
\text { (CCAR) (including capital plan) }\end{array}$ & $\begin{array}{l}\text { EU stress test (for SSM banks: as part of } \\
\text { the comprehensive assessment) }\end{array}$ \\
\hline $\begin{array}{l}\text { Treatment of } \\
\text { large banks }\end{array}$ & $\begin{array}{l}\text { BHCs have to meet different expectations, } \\
\text { based on size, scope of operation, activities, } \\
\text { and systemic importance }\end{array}$ & $\begin{array}{l}\text { No such distinction (except for NCA } \\
\text { special requirements) }\end{array}$ \\
\hline $\begin{array}{l}\text { Regularity of } \\
\text { exercise }\end{array}$ & Annual exercise, according to set timetable & $\begin{array}{l}\text { Annual national tests planned, but not yet } \\
\text { clear whether these will be EU-wide }\end{array}$ \\
\hline Timing & $\begin{array}{l}1 \text { November 2013: Instructions for CCAR } \\
2014 \text { exercise; } \\
6 \text { January 2014: Deadline for capital plans; } \\
\text { March 2014: Publication of results; } \\
\text { Original June resubmission deadline for } \\
\text { capital plans, then extended to January }\end{array}$ & $\begin{array}{l}\text { Supervisory Risk Assessment in Q4/2013; } \\
\text { AQR in Q1 and Q2/2014; stress test } \\
\text { (partly overlapping with AQR) in Q2 and } \\
\text { Q3/2014; publication of results from } \\
\text { AQR and stress test: October 2014; } \\
\text { upon release, banks falling below the } \\
\text { regulatory thresholds submit a } \\
\text { recapitalization plan in } 6 \text { - } 9 \text { months to } \\
\text { address capital shortfalls }\end{array}$ \\
\hline $\begin{array}{l}\text { Role of } \\
\text { supervisor in } \\
\text { evaluation of } \\
\text { banks }\end{array}$ & $\begin{array}{l}\text { Conduct of DFA supervisory stress test, } \\
\text { qualitative checks on company-run tests, and } \\
\text { quantitative assessment in CCAR; disclosure } \\
\text { of results; decisions on submitted capital } \\
\text { plans }\end{array}$ & $\begin{array}{l}\text { NCAs: Checks for quality, consistency, } \\
\text { and coherence of bank-submitted results } \\
\text { at the national level; } \\
\text { ECB: Second checks for Eurozone } \\
\text { countries; } \\
\text { EBA: Disclosure of results }\end{array}$ \\
\hline
\end{tabular}

\footnotetext{
${ }^{34}$ Note that there are also stress tests carried out on firms that are $€ 10-€ 50$ billion in size, which did not participate in the CCAR exercise.
} 


\begin{tabular}{|c|c|c|}
\hline Dimension & CCAR 2014 & EBA 2014 \\
\hline $\begin{array}{l}\text { Time horizon } \\
\text { adverse scenario }\end{array}$ & Nine quarters, Q4/2013 until Q4/2015 & Twelve quarters: 2014-2016 \\
\hline $\begin{array}{l}\text { General } \\
\text { comments }\end{array}$ & $\begin{array}{l}\text { Scenarios designed by Fed: Baseline, } \\
\text { adverse, and severely adverse; additional } \\
\text { scenarios or components of scenarios for } \\
\text { all or a subset of the companies possible }\end{array}$ & $\begin{array}{l}\text { Designed by European Commission } \\
\text { (baseline scenario) and ESRB (adverse } \\
\text { scenario); NCAs can extend scenarios }\end{array}$ \\
\hline $\begin{array}{l}\text { Specific } \\
\text { scenarios }\end{array}$ & $\begin{array}{l}\text { Adverse scenario: Global aversion to long- } \\
\text { term debt instruments; } \\
\text { Severely adverse scenario: Significant } \\
\text { reversal of recent improvements to the U.S. } \\
\text { housing market and the eurozone outlook; } \\
\text { Real GDP: }-4.75 \% \text { by Q4/2014, }-1 \% \text { by } \\
\text { Q4/2015, }+1.5 \% \text { by Q4/2016 } \\
\text { Equity prices: }-50 \% \text {, house prices: - } 25 \%\end{array}$ & $\begin{array}{l}\text { Adverse scenario: Increase in global bond } \\
\text { yields, further deterioration of credit } \\
\text { quality in countries with feeble demand, } \\
\text { stalling policy reforms, lack of bank } \\
\text { balance sheet repair; } \\
\text { EU GDP: }-0.7 \% \text { (2014), }-3.6 \% \text { (2015), - } \\
5.2 \% \text { (2016) } \\
\text { EU unemployment relative to baseline: } \\
+0.6 \% \text { (2014), }+1.9 \% \text { (2015), } 2.9 \% \\
\text { (2016) } \\
\text { Equity prices: }-15 \% \text {, house prices: }-8-11 \%\end{array}$ \\
\hline $\begin{array}{l}\text { Company- } \\
\text { specific } \\
\text { scenarios }\end{array}$ & BHC baseline and stress scenario & Not applicable in the EU context \\
\hline
\end{tabular}

\section{Regulatory Thresholds}

\begin{tabular}{lll}
\hline Dimension & CCAR 2014 & EBA 2014 \\
\hline $\begin{array}{l}\text { Legal basis for } \\
\text { regulatory ratios }\end{array}$ & $\begin{array}{l}\text { Basel III regulatory capital reforms as } \\
\text { approved by Board of Governors of the } \\
\text { Federal Reserve in July 2013, with } \\
\text { transitional rules ("phase-in") over } \\
\text { planning horizon }\end{array}$ & $\begin{array}{l}\text { Capital definition as in CRR/CRD IV, } \\
\text { with transitional rules as per December } \\
\text { 2013, December 2014, December 2015, } \\
\text { December 2016 }\end{array}$ \\
$\begin{array}{ll}\text { Regulatory } \\
\text { thresholds }\end{array}$ & $\begin{array}{l}\text { Tier 1 Common ratio: 5\% in all quarters; } \\
\text { CET1 ratio: n/a for Q4/2013, 4\% in 2014, }\end{array}$ & $\begin{array}{l}\text { One regulatory ratio: CET1 ratio was 8\% } \\
\text { for baseline scenario, 5.5\% for adverse } \\
\text { scenario (while 2011: 5\% threshold for } \\
\text { both scenarios); NCAs may set additional } \\
\text { ratios and thresholds }\end{array}$ \\
& $\begin{array}{l}\text { 4.5\% in 2015; } \\
\text { Tier 1 risk-based ratio: 4\% for Q4/2013, } \\
\text { 5.5\% in 2014, 6\% in 2015; }\end{array}$ & \\
& $\begin{array}{l}\text { Total Risk-based Capital Ratio: 8\% in all } \\
\text { quarters; }\end{array}$ & \\
& $\begin{array}{l}\text { Tier 1 leverage ratio: 3\% or 4\% for } \\
\text { Q4/2013, 4 \% in 2014, 4\% in 2015 }\end{array}$ & \\
\hline
\end{tabular}

Other Details

\begin{tabular}{lll}
\hline Dimension & CCAR 2014 & EBA 2014 \\
\hline $\begin{array}{l}\text { Static balance } \\
\text { sheet constraint }\end{array}$ & Evolving balance sheets & Balance sheet is static \\
$\begin{array}{l}\text { Micro vs. } \\
\text { macroprudential } \\
\text { exercise }\end{array}$ & $\begin{array}{l}\text { Microeconomic exercise with } \\
\text { macroeconomic objective }\end{array}$ & $\begin{array}{l}\text { Microeconomic exercise with } \\
\text { macroeconomic objective }\end{array}$ \\
$\begin{array}{l}\text { Accounting for } \\
\text { geographic } \\
\text { heterogeneity }\end{array}$ & $\begin{array}{l}\text { Not addressing geographic } \\
\text { heterogeneity in scenarios; adaption in } \\
\text { stress testing }\end{array}$ & $\begin{array}{l}\text { Heterogeneous development across the } \\
\text { eurozone }\end{array}$ \\
\hline
\end{tabular}




\begin{tabular}{|c|c|c|}
\hline Dimension & CCAR 2014 & EBA 2014 \\
\hline $\begin{array}{l}\text { Decision on } \\
\text { Recapitalization }\end{array}$ & $\begin{array}{l}\text { Decision by the Fed based on } \\
\text { qualitative or quantitative } \\
\text { assessment in CCAR }\end{array}$ & At the discretion of NCAs \\
\hline $\begin{array}{l}\text { Recapitalization } \\
\text { device }\end{array}$ & $\begin{array}{l}\text { No explicit recapitalization device } \\
\text { (in contrast to SCAP 2009); } \\
\text { objection to capital plans leads to } \\
\text { ban on capital actions }\end{array}$ & No central backstop mechanism \\
\hline $\begin{array}{l}\text { Addressing } \\
\text { levels rather } \\
\text { than ratios }\end{array}$ & $\begin{array}{l}\text { Banks are to meet detected capital } \\
\text { short falls by adjusting their planned } \\
\text { capital actions }\end{array}$ & $\begin{array}{l}\text { No clear stand on banks having to address equity } \\
\text { rather than RWAs }\end{array}$ \\
\hline \multicolumn{3}{|l|}{ Results } \\
\hline Dimension & CCAR 2014 & EBA 2014 \\
\hline Results & $\begin{array}{l}\text { Fed objected to capital plans of five } \\
\text { banks: Citigroup, HSBC North } \\
\text { America, RBS, Santander } \\
\text { (qualitative assessment), Zions } \\
\text { Bancorporation (quantitative } \\
\text { assessment) }\end{array}$ & (Not yet known) \\
\hline
\end{tabular}

Source: EBA (2014), ECB (2013, 2014c), Fed (2013, 2014a, 2014b) 


\section{Annex IV. Assessing European Banks in 2011 Using Public Data}

Annex I provides a brief summary of the methodology used to construct the ranking of the banks as reported in Table 1 and is based on Acharya and Steffen (2013).

I construct a sample of publicly listed banks, including all listed banks from the official 2010 and 2011 European stress tests and add large, publicly listed European banks that either are not EU members (e.g., UBS and Credit Suisse) or that had already failed by the summer of 2010 (e.g., the Anglo Irish Bank). Overall, 63 banks are analysed as part of the sample, and a list of these banks is provided in Annex I. Approximately $60 \%$ of all banks come from six countries: Spain (8), Italy (7), Germany (6), Greece (6), the United Kingdom (6), and France (4). Stock prices, indices, and balance sheet information are downloaded from Bloomberg.

Acharya, Pedersen, Philippon, and Richardson (2010) show that the systemic expected shortfall (SES) is the market value amount of equity a bank drops below its target value conditioned on the aggregate capital falling below a target value (which is the definition of an extreme tail event). They demonstrate that SES can be explained by two factors. The first factor is the ex ante leverage ratio of the bank; the second factor is a term that captures the performance of the bank when an extreme tail event happens. Intuitively, a bank that is already undercapitalized once a systemic crisis occurs needs more capital (e.g., capital injections or bailouts for depositors), as does a bank with a high sensitivity to an extreme event. Ideally, a bank with a business model that is highly sensitive to extreme market movements should operate with significantly lower leverage ratios relative to a bank that is less sensitive.

I employ the best fit of realized returns during the financial crisis (July 2007 to Dec 2008), as explained by both MES, LVG, and Log Assets to construct a fitted systemic risk measure and rank firms using this fit. MES is the marginal expected shortfall based on Acharya et al. (2010), which measures the performance of a bank when the market return as a whole (MSCI Europe index) experiences its worst 5\% trading days within a year. LVG is the bank's (quasi-) market leverage ratio, which is its (quasi-) market value of assets divided by market value of equity. Log Assets is the natural logarithm of the banks' total assets. Thus, the ranking is based on the following model:

$$
\text { SES }(\text { Fitted })=-0.73-10.41 * \text { MES }-0.005 * \text { LVG }+0.02 * \text { Log Assets. }
$$

In other words, this stress scenario resembles the financial crisis of 2007-2009. 


\section{Annex V. ECB Stress Test Banks 2014}

\begin{tabular}{|c|c|c|c|c|c|c|}
\hline Bank & Country & Ticker & Assets & C Tier 1 & Equity/Assets & RWA/Assets \\
\hline Erste Group Bank & Austria & EBS & 199,876 & $11.44 \%$ & $7.40 \%$ & $48.98 \%$ \\
\hline Raiffeisen Zentralbank & Austria & & 147,324 & $9.93 \%$ & $8.00 \%$ & $60.47 \%$ \\
\hline Raiffeisenlandesbank OÖ AG & Austria & & 37,431 & $9.80 \%$ & $9.46 \%$ & $70.43 \%$ \\
\hline BAWAG P.S.K. & Austria & & 36,402 & $15.56 \%$ & $7.69 \%$ & $43.96 \%$ \\
\hline Raiffeisenlandesbank NÖ-Wien & Austria & & 32,310 & $10.31 \%$ & $7.50 \%$ & $44.04 \%$ \\
\hline Österreichische Volksbanken & Austria & VBPS & 20,904 & $13.56 \%$ & $5.84 \%$ & $53.91 \%$ \\
\hline KBC Group & Belgium & $\mathrm{KBC}$ & 241,306 & $13.46 \%$ & $6.01 \%$ & $37.52 \%$ \\
\hline Dexia & Belgium & DEXB & 222,936 & $21.24 \%$ & $1.78 \%$ & $21.23 \%$ \\
\hline Belfius Banque & Belgium & & 182,777 & $15.36 \%$ & $3.62 \%$ & $23.40 \%$ \\
\hline AXA Bank Europe & Belgium & & 39,217 & $16.52 \%$ & $2.10 \%$ & $12.54 \%$ \\
\hline Argenta Bank & Belgium & & 35,416 & & $4.02 \%$ & \\
\hline Bank of Cyprus & Cyprus & BOCY & 30,342 & $10.17 \%$ & $9.00 \%$ & $73.96 \%$ \\
\hline Hellenic Bank & Cyprus & $\mathrm{HB}$ & 6,384 & $7.30 \%$ & $5.54 \%$ & $68.92 \%$ \\
\hline Cooperative Central Bank Ltd & Cyprus & & 4,561 & $17.89 \%$ & $5.86 \%$ & $22.60 \%$ \\
\hline Swedbank AS & Estonia & & 8,932 & $34.69 \%$ & $21.18 \%$ & $46.80 \%$ \\
\hline SEB Pank AS & Estonia & & 4,443 & $36.14 \%$ & $17.43 \%$ & $48.21 \%$ \\
\hline Nordea Bank Finland & Finland & & 304,761 & $16.01 \%$ & $3.12 \%$ & $17.28 \%$ \\
\hline OP-Pohjola Group & Finland & & 100,981 & $17.31 \%$ & $7.64 \%$ & $33.76 \%$ \\
\hline Danske Bank & Finland & & 26,680 & $15.65 \%$ & $8.93 \%$ & $55.79 \%$ \\
\hline BNP Paribas & France & $\mathrm{BNP}$ & $1,810,535$ & $11.73 \%$ & $5.02 \%$ & $30.93 \%$ \\
\hline Crédit Agricole SA & France & $\mathrm{ACA}$ & $1,536,873$ & $9.96 \%$ & $3.12 \%$ & $19.49 \%$ \\
\hline Société Générale & France & GLE & $1,235,262$ & $11.27 \%$ & $4.38 \%$ & $25.54 \%$ \\
\hline Groupe BPCE & France & & $1,123,520$ & $11.37 \%$ & $5.18 \%$ & $32.84 \%$ \\
\hline Crédit Mutuel Group & France & & 645,216 & $13.30 \%$ & $5.95 \%$ & $29.96 \%$ \\
\hline HSBC France & France & & 208,893 & $15.01 \%$ & $2.60 \%$ & $14.12 \%$ \\
\hline La Banque Postale & France & & 200,232 & $11.44 \%$ & $3.49 \%$ & $22.59 \%$ \\
\hline Caisse Française & France & & 80,017 & & $1.70 \%$ & \\
\hline Caisse de Refinancement & France & & 53,134 & & $0.59 \%$ & \\
\hline Bpifrance Financement SA & France & & 29,941 & $10.48 \%$ & $9.00 \%$ & $83.12 \%$ \\
\hline RCI Banque SA & France & & 29,505 & $14.20 \%$ & $9.91 \%$ & $59.72 \%$ \\
\hline Deutsche Bank & Germany & DBK & $1,611,400$ & $12.83 \%$ & $3.41 \%$ & $18.64 \%$ \\
\hline Commerzbank & Germany & CBK & 549,661 & $13.06 \%$ & $4.90 \%$ & $34.67 \%$ \\
\hline DZ Bank AG & Germany & & 386,978 & $13.50 \%$ & $3.66 \%$ & $22.06 \%$ \\
\hline Landesbank Baden-Württemberg & Germany & & 273,523 & $15.67 \%$ & $4.90 \%$ & $29.01 \%$ \\
\hline Bayerische Landesbank & Germany & & 255,601 & $15.76 \%$ & $5.82 \%$ & $34.25 \%$ \\
\hline NORD/LB & Germany & & 200,845 & $10.64 \%$ & $4.08 \%$ & $34.10 \%$ \\
\hline Landesbank Hessen-Thüringen & Germany & & 178,083 & $11.00 \%$ & $3.98 \%$ & $30.36 \%$ \\
\hline NRW.BANK & Germany & & 145,350 & $44.02 \%$ & $12.30 \%$ & $26.71 \%$ \\
\hline HRE Holding AG & Germany & & 122,454 & $30.91 \%$ & $5.18 \%$ & $10.84 \%$ \\
\hline DekaBank Deutsche Girozentrale & Germany & & 116,073 & $13.10 \%$ & $3.25 \%$ & $19.35 \%$ \\
\hline HSH Nordbank & Germany & & 109,022 & $11.70 \%$ & $4.15 \%$ & $32.65 \%$ \\
\hline Landesbank Berlin Holding AG & Germany & & 102,437 & $9.28 \%$ & $2.29 \%$ & $25.02 \%$ \\
\hline Westdeutsche Genossenschafts & Germany & & 90,900 & $12.20 \%$ & $3.18 \%$ & $18.32 \%$ \\
\hline Landwirtschaftliche Rentenbank & Germany & & 81,932 & $23.90 \%$ & $3.90 \%$ & $16.54 \%$ \\
\hline Wüstenrot \& Württembergische & Germany & & 75,043 & & $4.33 \%$ & \\
\hline L-Bank Baden-Württemberg & Germany & & 70,630 & $14.15 \%$ & $4.06 \%$ & $26.02 \%$ \\
\hline Aareal Bank & Germany & ARL & 42,981 & $15.93 \%$ & $5.70 \%$ & $30.59 \%$ \\
\hline Hamburger Sparkasse & Germany & & 40,521 & $9.30 \%$ & $6.57 \%$ & \\
\hline Volkswagen Bank GmbH & Germany & & 39,378 & $14.03 \%$ & $11.93 \%$ & $75.05 \%$ \\
\hline SEB AG & Germany & & 35,634 & $12.18 \%$ & $5.78 \%$ & $35.63 \%$ \\
\hline Münchener Hypothekenbank & Germany & & 34,899 & $6.30 \%$ & $2.55 \%$ & $22.62 \%$ \\
\hline Deutsche Apotheker & Germany & & 34,695 & $16.96 \%$ & $6.34 \%$ & $31.42 \%$ \\
\hline IKB Deutsche Industriebank & Germany & & 27,617 & $6.63 \%$ & $4.07 \%$ & $57.08 \%$ \\
\hline KfW IPEX-Bank GmbH & Germany & & 23,437 & $18.09 \%$ & $13.62 \%$ & $78.18 \%$ \\
\hline National Bank of Greece & Greece & ETE & 110,930 & $10.30 \%$ & $7.10 \%$ & $61.57 \%$ \\
\hline Piraeus Bank & Greece & TPEIR & 92,010 & $13.88 \%$ & $9.28 \%$ & $64.16 \%$ \\
\hline Eurobank Ergasias & Greece & EUROB & 77,586 & $10.43 \%$ & $5.83 \%$ & $49.15 \%$ \\
\hline Alpha Bank & Greece & ALPHA & 73,697 & $15.94 \%$ & $11.35 \%$ & $69.88 \%$ \\
\hline Bank of Ireland & Ireland & BIR & 132,137 & $12.23 \%$ & $5.96 \%$ & $42.68 \%$ \\
\hline Allied Irish Banks & Ireland & AIB & 117,734 & $14.56 \%$ & $8.91 \%$ & $53.00 \%$ \\
\hline Ulster Bank Ireland Ltd. & Ireland & & 40,912 & $11.58 \%$ & $20.16 \%$ & $110.70 \%$ \\
\hline Permanent TSB Group Hldgs Plc & Ireland & ILO & 37,601 & $13.11 \%$ & $6.34 \%$ & $45.09 \%$ \\
\hline
\end{tabular}




\begin{tabular}{|c|c|c|c|c|c|c|}
\hline UniCredit & Italy & UCG & 845,838 & $10.57 \%$ & $5.93 \%$ & $45.49 \%$ \\
\hline Intesa Sanpaolo & Italy & ISP & 626,283 & $11.33 \%$ & $7.19 \%$ & $44.12 \%$ \\
\hline Banca Monte dei Paschi & Italy & BMPS & 199,106 & $10.65 \%$ & $3.10 \%$ & $39.38 \%$ \\
\hline Banco Popolare & Italy & $\mathrm{BP}$ & 126,043 & $9.70 \%$ & $6.76 \%$ & $39.13 \%$ \\
\hline UBI Banca & Italy & UBI & 124,242 & $12.60 \%$ & $9.00 \%$ & $49.13 \%$ \\
\hline Mediobanca & Italy & MB & 72,841 & $11.75 \%$ & $9.54 \%$ & $71.90 \%$ \\
\hline Banca popolare dell'Emilia & Italy & BPE & 61,758 & $8.56 \%$ & $7.63 \%$ & $69.57 \%$ \\
\hline Banca Popolare di Milano & Italy & PMI & 49,353 & $7.21 \%$ & $7.39 \%$ & $86.34 \%$ \\
\hline Banca Popolare di Vicenza & Italy & & 45,235 & $9.21 \%$ & $8.11 \%$ & $62.03 \%$ \\
\hline Banca Carige & Italy & CRG & 42,156 & $5.09 \%$ & $3.90 \%$ & $51.12 \%$ \\
\hline Iccrea Holding & Italy & & 40,045 & $9.27 \%$ & $3.68 \%$ & $35.20 \%$ \\
\hline Veneto Banca & Italy & & 37,307 & $7.15 \%$ & $8.49 \%$ & $66.77 \%$ \\
\hline Banca Popolare di Sondrio & Italy & BPSO & 32,770 & $7.89 \%$ & $6.14 \%$ & $72.49 \%$ \\
\hline Credito Emiliano & Italy & $\mathrm{CE}$ & 31,531 & $9.94 \%$ & $6.84 \%$ & $52.41 \%$ \\
\hline Credito Valtellinese & Italy & & 27,199 & $8.63 \%$ & $7.03 \%$ & $64.34 \%$ \\
\hline Swedbank AS & Latvia & & 5,054 & $28.06 \%$ & $20.20 \%$ & $62.54 \%$ \\
\hline SEB Banka & Latvia & & 4,271 & $15.60 \%$ & $10.20 \%$ & $60.48 \%$ \\
\hline ABLV Bank AS & Latvia & & 3,317 & $11.35 \%$ & $5.71 \%$ & $48.27 \%$ \\
\hline Banque et Caisse d'Epargne & Luxembourg & & 40,714 & $16.64 \%$ & $9.14 \%$ & $30.50 \%$ \\
\hline Banque Intl. Luxembourg & Luxembourg & & 21,306 & $14.39 \%$ & $5.19 \%$ & $19.75 \%$ \\
\hline RBC Investor Services Bank SA & Luxembourg & & 12,574 & $27.31 \%$ & $7.28 \%$ & $20.13 \%$ \\
\hline KBL European Private Bankers & Luxembourg & & 12,469 & $13.53 \%$ & $8.02 \%$ & $30.96 \%$ \\
\hline UBS (Luxembourg) SA & Luxembourg & & 9,325 & & $6.48 \%$ & \\
\hline Bank of Valletta & Malta & BOV & 7,258 & $11.67 \%$ & $7.95 \%$ & $49.47 \%$ \\
\hline HSBC Bank Malta & Malta & HSB & 5,722 & $9.39 \%$ & $7.39 \%$ & $49.40 \%$ \\
\hline ING Bank & Netherlands & & 787,644 & $11.72 \%$ & $4.29 \%$ & $35.87 \%$ \\
\hline Rabobank Nederland & Netherlands & & 479,544 & $13.54 \%$ & $3.96 \%$ & $43.96 \%$ \\
\hline ABN AMRO Group & Netherlands & & 372,022 & $14.40 \%$ & $3.65 \%$ & $29.30 \%$ \\
\hline NV Bk Nederlandse Gemeenten & Netherlands & & 131,183 & $21.96 \%$ & $2.61 \%$ & $8.25 \%$ \\
\hline SNS Bank NV & Netherlands & & 74,537 & $16.57 \%$ & $3.46 \%$ & $19.56 \%$ \\
\hline Nederlandse Waterschapsbank & Netherlands & & 73,006 & $100.88 \%$ & $1.72 \%$ & $1.71 \%$ \\
\hline Royal Bank of Scotland NV & Netherlands & & 39,808 & $20.48 \%$ & $7.39 \%$ & $43.67 \%$ \\
\hline Caixa Geral & Portugal & & 112,963 & $11.50 \%$ & $6.05 \%$ & $58.52 \%$ \\
\hline Millennium BCP & Portugal & $\mathrm{BCP}$ & 82,007 & $13.75 \%$ & $3.99 \%$ & $53.56 \%$ \\
\hline Banco Espírito Santo & Portugal & ESF & 80,608 & $10.61 \%$ & $8.75 \%$ & $71.12 \%$ \\
\hline Banco BPI & Portugal & BPI & 42,700 & $16.54 \%$ & $5.40 \%$ & $49.22 \%$ \\
\hline Slovenska Sporitelna & Slovakia & & 11,699 & $22.33 \%$ & $11.04 \%$ & $37.30 \%$ \\
\hline VUB Banka & Slovakia & 1VUB02AE & 11,556 & $15.93 \%$ & $11.94 \%$ & $59.00 \%$ \\
\hline Tatra Banka a.s. & Slovakia & & 9,469 & $15.44 \%$ & $10.70 \%$ & $56.91 \%$ \\
\hline Nova Ljubljanska Banka & Slovenia & & 12,490 & $8.77 \%$ & $10.18 \%$ & $77.12 \%$ \\
\hline Nova Kreditna Banka & Slovenia & & 4,830 & $19.10 \%$ & $12.38 \%$ & $81.25 \%$ \\
\hline SID - Slovenska Izvozna & Slovenia & & 3,940 & $13.83 \%$ & $9.49 \%$ & $57.13 \%$ \\
\hline Banco Santander & Spain & SAN & $1,115,638$ & $11.71 \%$ & $7.16 \%$ & $43.90 \%$ \\
\hline BBVA & Spain & BBVA & 599,517 & $11.59 \%$ & $7.48 \%$ & $53.98 \%$ \\
\hline La Caixa & Spain & & 351,269 & $12.73 \%$ & $7.75 \%$ & $39.62 \%$ \\
\hline Banco Financiero y de Ahorros & Spain & & 269,159 & $11.97 \%$ & $4.57 \%$ & $35.11 \%$ \\
\hline Banco de Sabadell & Spain & SAB & 163,441 & $11.96 \%$ & $6.37 \%$ & $44.59 \%$ \\
\hline Banco Popular Español & Spain & POP & 146,709 & $10.25 \%$ & $7.92 \%$ & $56.31 \%$ \\
\hline Ibercaja Banco SA & Spain & & 63,118 & $10.29 \%$ & $4.14 \%$ & $38.08 \%$ \\
\hline CatalunyaBanc & Spain & & 63,062 & $3.55 \%$ & $4.02 \%$ & $28.74 \%$ \\
\hline Kutxabank SA & Spain & & 60,762 & $11.97 \%$ & $8.08 \%$ & $60.28 \%$ \\
\hline Bankinter & Spain & BKT & 55,136 & $12.85 \%$ & $6.17 \%$ & $41.31 \%$ \\
\hline NCG Banco SA & Spain & & 52,687 & $11.60 \%$ & $5.15 \%$ & $47.80 \%$ \\
\hline Banco Mare Nostrum & Spain & & 47,518 & $10.40 \%$ & $4.38 \%$ & $42.10 \%$ \\
\hline Liberbank SA & Spain & & 44,546 & $10.39 \%$ & $3.56 \%$ & $38.38 \%$ \\
\hline Cajas Rurales Unidas SCC & Spain & & 42,104 & $10.84 \%$ & $6.60 \%$ & $50.97 \%$ \\
\hline Unicaja Banco SA & Spain & & 41,243 & $12.86 \%$ & $5.05 \%$ & $38.84 \%$ \\
\hline Banco de CEISS SA & Spain & & 35,527 & $-3.06 \%$ & $1.84 \%$ & $38.70 \%$ \\
\hline
\end{tabular}


Annex VI. Capital Shortfall Based on SRISK

This table is a ranking of the public banks sorted by their systemic expected capital shortfall.

\begin{tabular}{|c|c|c|c|c|c|c|}
\hline Bank & Country & Ticker & Market Cap & $\begin{array}{c}\text { Market Equity/ } \\
\text { Assets }\end{array}$ & $\begin{array}{c}\text { LRMES* } \\
\text { Market Cap }\end{array}$ & $\begin{array}{c}\text { SRISK } \\
5.5 \% \\
\end{array}$ \\
\hline Crédit Agricole SA & France & $\mathrm{ACA}$ & 23,316 & $1.36 \%$ & 10,852 & 81,523 \\
\hline Deutsche Bank & Germany & DBK & 35,466 & $2.04 \%$ & 17,407 & 76,598 \\
\hline BNP Paribas & France & $\mathrm{BNP}$ & 70,611 & $4.05 \%$ & 34,767 & 58,034 \\
\hline Société Générale & France & GLE & 33,769 & $2.78 \%$ & 17,461 & 49,485 \\
\hline UniCredit & Italy & UCG & 31,267 & $3.74 \%$ & 16,530 & 30,361 \\
\hline Commerzbank & Germany & CBK & 13,375 & $2.34 \%$ & 6,599 & 24,246 \\
\hline Banco Santander & Spain & SAN & 73,826 & $6.33 \%$ & 35,465 & 23,832 \\
\hline Dexia & Belgium & DEXB & 78 & $0.02 \%$ & 23 & 21,354 \\
\hline Intesa Sanpaolo & Italy & ISP & 29,269 & $4.80 \%$ & 15,293 & 18,698 \\
\hline Banca Monte dei Paschi & Italy & BMPS & 2,056 & $1.03 \%$ & 1,020 & 9,865 \\
\hline Erste Group Bank & Austria & EBS & 10,922 & $5.45 \%$ & 6,175 & 5,932 \\
\hline BBVA & Spain & BBVA & 51,866 & $8.61 \%$ & 25,752 & 5,611 \\
\hline Banco Popolare & Italy & $\mathrm{BP}$ & 2,467 & $2.03 \%$ & 1,404 & 5,528 \\
\hline KBC Group & Belgium & $\mathrm{KBC}$ & 17,227 & $6.92 \%$ & 9,302 & 5,262 \\
\hline Banco de Sabadell & Spain & SAB & 7,590 & $4.63 \%$ & 3,073 & 4,334 \\
\hline UBI Banca & Italy & UBI & 4,466 & $3.82 \%$ & 2,037 & 3,881 \\
\hline Banco Popular Español & Spain & POP & 8,327 & $5.58 \%$ & 4,029 & 3,690 \\
\hline Banco Espírito Santo & Portugal & ESF & 1,007 & $1.32 \%$ & 206 & 3,381 \\
\hline Millennium BCP & Portugal & $\mathrm{BCP}$ & 3,285 & $4.02 \%$ & 1,578 & 2,701 \\
\hline Eurobank Ergasias & Greece & EUROB & 3,029 & $3.96 \%$ & 1,373 & 2,471 \\
\hline Bank of Ireland & Ireland & BIR & 8,170 & $6.40 \%$ & 3,507 & 2,161 \\
\hline Banca Popolare dell'Emilia & Italy & BPE & 2,317 & $3.98 \%$ & 1,059 & 1,881 \\
\hline Banca Popolare di Milano & Italy & PMI & 1,458 & $3.09 \%$ & 745 & 1,845 \\
\hline Banca Carige & Italy & CRG & 974 & $2.31 \%$ & 406 & 1,725 \\
\hline Aareal Bank & Germany & ARL & 1,729 & $4.12 \%$ & 1,038 & 1,562 \\
\hline Piraeus Bank & Greece & TPEIR & 7,770 & $8.64 \%$ & 4,202 & 1,146 \\
\hline Banco BPI & Portugal & BPI & 1,693 & $4.05 \%$ & 543 & 1,120 \\
\hline Mediobanca & Italy & MB & 5,495 & $7.40 \%$ & 2,579 & 1,028 \\
\hline Banca Popolare di Sondrio & Italy & BPSO & 1,295 & $4.06 \%$ & 592 & 1,020 \\
\hline Permanent TSB Group Hldgs Plc & Ireland & IL0 & 1,646 & $4.65 \%$ & 627 & 892 \\
\hline Österreichische Volksbanken & Austria & VBPS & 530 & $2.39 \%$ & 57 & 745 \\
\hline National Bank of Greece & Greece & ETE & 9,242 & $8.28 \%$ & 3,919 & 597 \\
\hline Credito Emiliano & Italy & $\mathrm{CE}$ & 1,939 & $6.42 \%$ & 776 & 455 \\
\hline Bankinter & Spain & BKT & 4,474 & $7.72 \%$ & 1,835 & 448 \\
\hline Hellenic Bank & Cyprus & $\mathrm{HB}$ & 229 & $3.75 \%$ & 64 & 167 \\
\hline Alpha Bank & Greece & ALPHA & 6,905 & $9.68 \%$ & 3,307 & 145 \\
\hline VUB Banka & Slovakia & 1VUB02AE & 964 & $9.20 \%$ & 139 & 0 \\
\hline Bank of Valletta & Malta & BOV & 797 & $11.36 \%$ & 124 & 0 \\
\hline Allied Irish Banks & Ireland & AIB & 58,487 & $35.99 \%$ & 26,058 & 0 \\
\hline HSBC Bank Malta & Malta & HSB & 759 & $12.61 \%$ & 115 & 0 \\
\hline
\end{tabular}

